\title{
Effect of Hydrated Lime on Indirect Tensile Stiffness Modulus of Asphalt Concrete Produced in Half-Warm Mix Technology
}

\author{
Mateusz M. Iwański (D) \\ Department of Building Engineering Technologies and Organization, \\ Faculty of Civil Engineering and Architecture, Kielce University of Technology, Al. Tysiąclecia Państwa \\ Polskiego 7, 25-314 Kielce, Poland; matiwanski@tu.kielce.pl
}

Received: 8 September 2020; Accepted: 20 October 2020; Published: 23 October 2020

\begin{abstract}
Half-warm mix asphalt (HWMA) mixtures can be produced at temperatures ranging from $100{ }^{\circ} \mathrm{C}$ to $130{ }^{\circ} \mathrm{C}$, depending on the production methods used. The lowest mixing temperature can be achieved by using water-foamed bitumen. The mixture should be characterized by a long service life, defined by the resistance to permanent deformation and high stiffness modulus at temperatures above zero. It is therefore important to ensure the adequately high quality of the bitumen binder. Bitumen 50/70 was provided with appropriate quality foaming characteristics (expansion ratio, ER, half-life, $\mathrm{t} 1 / 2)$ by adding a surface-active agent (SAA) at $0.6 \mathrm{wt} \%$ before foaming. Then asphalt concrete (AC) $8 \mathrm{~S}$ was designed and produced with the recommended water-foamed binder. Hydrated lime, an additive substantially affecting asphalt concrete mechanical parameters, was used at $0,15,30$, and $45 \mathrm{wt} \%$ as a partial replacement for the limestone filler. The influence of the amount of hydrated lime on the content of voids, indirect tensile stiffness modulus at $-10{ }^{\circ} \mathrm{C}, 0{ }^{\circ} \mathrm{C},+10{ }^{\circ} \mathrm{C},+20^{\circ} \mathrm{C}$, and $+30^{\circ} \mathrm{C}$, and the resistance to permanent deformation was investigated. Statistical analysis of the test results showed the quantity of $30 \%$ to be the optimum hydrated lime content. The AC $8 \mathrm{~S}$ resistance to permanent deformation was determined at the optimum hydrated lime content. The comprehensive evaluation revealed a synergistic effect between bitumen 50/70, modified before foaming with $0.6 \mathrm{wt} \% \mathrm{SAA}$ and $30 \mathrm{wt} \%$ hydrated lime as the limestone filler replacement, and the half warm mixture AC $8 \mathrm{~S}$, in terms of the standard requirements and durability of the HWMA concrete in pavement applications.
\end{abstract}

Keywords: asphalt concrete; foamed bitumen; half-warm mix asphalt (HWMA); hydrated lime; indirect tensile stiffness modulus

\section{Introduction}

Half warm mix asphalt (HWMA) comprises the most environmentally friendly technologies of bituminous mixture production with water-foamed bitumen used as a binder [1-3]. Mixtures with foamed binders can be produced at temperatures $60{ }^{\circ} \mathrm{C}$ lower than the conventional mixture temperatures. Both HWMA and hot mix asphalt (HMA) are subject to the same performance criteria, with key characteristics being high stiffness modulus at temperatures above zero, and high resistance to permanent deformation.

A high level of bitumen foaming parameters (expansion ratio ER, half-life $t_{1 / 2}$ ) ensures proper mixture quality. As no formal requirements for the foaming parameters of water-foamed bitumen exist, the only applicable guidelines are those designed for cold recycling $[4,5]$. The properties of recycled mixtures with water-foamed bitumen have been widely investigated [6-9]. Several researchers have found that zeolite can be used to foam bitumen and bituminous mixtures instead of water, but this solution is used primarily with warm mix asphalt (WMA) [10-13]. 
The proper quality of the foam is ensured by adding various additives to the bitumen before foaming. Fischer-Tropsch (F-T) synthetic wax is the most commonly used additive [14-16]. Additives are also incorporated in bituminous mixtures made with foamed bitumen [14].

Following the modification, the bitumen foaming parameters $\left(E R, t_{1 / 2}\right)$ show markedly higher values compared with non-modified binders $[17,18]$. Adding F-T wax improves the standard and rheological properties of bitumen [19] and bituminous mixtures, especially in terms of deformation resistance [20,21]. The drawback of $\mathrm{F}-\mathrm{T}$ wax addition is its crystallization at temperatures below $90{ }^{\circ} \mathrm{C}$ [22]. As a result, at low temperatures, compaction is difficult, and the mixture fails to attain the required material parameters [23].

A fundamental issue concerning low temperature bituminous mixtures is securing proper compaction. As the quality of compaction may depend on the additive used, new types of chemical additives are being designed, with a view to improving mixture compaction at reduced temperatures [24,25]. Although effective in increasing mechanical characteristics, some of the additives reduce moisture resistance [25]. Various chemical additives have been studied in the process of investigating the effect of compaction on mixture parameters. It was found that both the type of additive and the method of compaction significantly affected mix properties. However, the test results obtained varied with the additive type and compaction method used, for example, the results from the gyratory press were found to be more beneficial than those from the traditional Marshall method [26]. A decline in the mixture parameters was recorded with the lowering of compaction temperature, except for the case when F-T synthetic wax was used. In another study [19], both compaction methods provided traditional mixtures with comparable properties in terms of resistance to permanent deformation, but the stiffness modulus and tensile strength decreased. Extensive comparative tests with chemical, organic, and zeolite additives [27] showed a significant effect of mixing and compaction temperatures on the gyratory compaction and mechanical properties, such as sensitivity to water and stiffness modulus. When the temperature was lowered, mixtures with additives required less compaction energy, their susceptibility to moisture improved in comparison with the control mixture, and the test temperature had a significant effect on the stiffness modulus.

As shown above, there is no clear-cut, unambiguous assessment of the influence of the additive type and compaction method on the properties of bituminous mixtures. Each case of additive application, as well as the choice of the compaction method, must be considered individually.

It is therefore necessary to continue the study in search of an additive that will ensure proper bitumen foaming, without adversely affecting the properties of bituminous mixtures at the service temperature of about $90^{\circ} \mathrm{C}$. The surface-active agent (SAA), which reduces bitumen viscosity, $[24,28]$ seems to be such an additive.

Exploratory research carried out in this respect confirmed a considerable influence of this additive on the bitumen foaming characteristics [29]. The studies and implementation practice to date show that SAA significantly improves the binder-aggregate adhesion in HMA, thus providing it with the required moisture and frost resistance. However, no improvement of bitumen properties has been observed after SAA incorporation. In some cases, a slight decline was reported [30]. Bituminous mixtures made with SAA-modified bitumen may exhibit less favorable properties than the mixtures containing non-modified bitumen [31]. Experience gained in HMA technology suggests that hydrated lime should be used in the research of foamed bitumen-based mixtures [32], since the lime has a substantial effect on the mix properties.

The use of hydrated lime as an additive to traditional HMA dates back over a hundred years [33,34].

Initially, the studies of hydrated lime addition focused on its influence on the adhesion between the mineral mixture and the binder. The positive results of those studies allowed expanding the scope of interest. It was confirmed that hydrated lime increased the resistance of the mixture to moisture and frost [35,36] as a result of improved adhesion of the bitumen to aggregate particles [37]. Its use is particularly important when using acidic aggregate (with $\mathrm{SiO}_{2}$ content $>65 \%$ ). The interaction 
mechanism is that calcium cations bond with silica compounds on the surface of the acidic aggregate, which results in the formation of strong ionic bonds.

It has been established that the mechanism of chemical interaction of hydrated lime on bitumen involves, first neutralizing bitumen polar molecules, and then their partial adsorption by hydrated lime molecules [38,39]. The remaining polar molecules of the bitumen, neutralized by the hydrated lime, do not diffuse to the bitumen-aggregate interface, but remain in the binder layer. The adhesion of the bituminous film to aggregates improves as the binder at the phase interface is neutral or alkaline [40-42].

Hydrated lime has been demonstrated to contribute to slowing down the rate of bitumen ageing, and hence the ageing of bituminous mixtures and pavements. This effect contributes to ensuring the durability of pavements throughout their service life [38,43].

The testing methodology includes two approaches. The first one is a laboratory-based approach in which bitumen is combined with hydrated lime or quicklime. The blend is then cured for a certain time, and then the lime is separated from the bitumen by extraction. The properties of the bitumen are determined at the end of this process [44-48]. The second method consists of testing bitumen recovered from pavement structural layers that were made of a bituminous mixture containing hydrated lime [49-51].

Tests of the binder recovered from bituminous mixtures used in the construction of structural layers are of particular importance in identifying the influence of hydrated lime on bitumen properties. It was found that the recovered binder exhibited higher viscosity than the binder that did not contain any surfactants [44]. A large number of studies have confirmed the positive role of hydrated lime in reducing the rate of changes in the properties of bitumen exposed to high temperatures during mixture production [52-57].

Hydrated lime is known to substantially increase the stiffness of the mastic defined by an increased softening point $[58,59]$. This parameter plays a very important role in ensuring the resistance of bituminous mixtures to permanent deformation. Increased mastic stiffness leads to increased rutting resistance. At the same time, excessive stiffness of the mastic may decrease the resistance of the bituminous mixture to fatigue and thermal cracking [60]. For these reasons, the amount of hydrated lime used needs to be limited and determined empirically. As such, hydrated lime can be used to control the stiffness of the mastic.

Hydrated lime has a positive effect on the mechanical characteristics of bituminous mixtures [61,62]. The dynamic modulus of bituminous mixtures, studied in the temperature range from $-10{ }^{\circ} \mathrm{C}$ to $+54.4{ }^{\circ} \mathrm{C}$ and at a frequency from $0.1 \mathrm{~Hz}$ to $25 \mathrm{~Hz}$, increased by $8 \%$ to $65 \%$, depending on the amount of hydrated lime dosed.

The influence of hydrated lime on the mechanical properties of bituminous mixtures has been studied extensively. Comprehensive research programs confirmed that the rut resistance of the mixture increases with increasing lime concentration, in the range from $2 \mathrm{wt} \%$ to $5 \mathrm{wt} \%$, or with its quantity up to $30 \%$, as a replacement of mineral filler in the mixture $[46,63,64]$.

Resistance to permanent deformation has been studied for the dosing method, which was found to strongly impact the intensity of the effects on the mixture properties [35].

Attempts to use hydrated lime have also been made in the production of WMA mixtures. The overall results of those studies revealed that hydrated lime contributes to ensuring resistance to moisture and frost $[65,66]$. However, there is limited experience in this area. The same effect has been confirmed by the exploratory studies of hydrated lime in HWMA concrete. Further research in this respect is needed [67].

To sum up, the problem of searching for a bitumen additive that allows lowering the mixing temperature of the bituminous mixture is still valid, especially when it is produced with water-foamed bitumen at about $100{ }^{\circ} \mathrm{C}$. Surface-agent additives are used to improve foaming parameters of the binder, and to secure the high quality of the bituminous mixture. The durability of the mixture is ensured by the use of hydrated lime. 
The beneficial effect of hydrated lime on a wide range of the properties of traditional HMA mixtures has already been confirmed. There is reason to believe that the same effects, that is, high values of the stiffness modulus and improved resistance to permanent deformation, will be confirmed for HWMA mixtures with water-foamed bitumen.

\section{Methodology}

\subsection{Material}

The laboratory test material was HWMA concrete AC $8 \mathrm{~S}$ produced with $5.6 \%$ foamed bitumen $50 / 70$, following the relevant requirements [68]. For reference purposes, the amount of binder was increased to $5.9 \%, 6.2 \%$, and $6.5 \%$. In this way, the increased demand for the binder, due to the use of hydrated lime in the asphalt concrete, was taken into account [28].

The bitumen used it the tests was a 50/70 paving grade bitumen, commonly used in the countries of central and eastern Europe in mixtures designed for pavements, under traffic characterized by $2.5 \times 10^{6}<$ ESAL $_{100 \mathrm{kN}}<7.3 \times 10^{6}$ (ESAL: equivalent single axle load) [69]. In Poland, it is the highest penetration bitumen that is permitted for use in bituminous mixtures designed for pavement wearing course [68]. The use of softer bitumen is not allowed due to the risk of permanent deformation.

Before foaming, the bitumen was modified with a $0.6 \%$ fatty acid amide-based surface active agent (SAA), by weight of the binder, to obtain high values of foaming characteristics. The properties of the SAA were as follows:

- appearance: brown viscous liquid,

- density at $20^{\circ} \mathrm{C}: 0.98 \mathrm{Mg} / \mathrm{m}^{3}$,

- pour point: $<0^{\circ} \mathrm{C}$,

- viscosity at $20^{\circ} \mathrm{C}: 3000 \mathrm{mP}$,

- viscosity at $50^{\circ} \mathrm{C}: 400 \mathrm{mP}$,

- amine index: $159-185 \mathrm{mg} \mathrm{HCl} / \mathrm{g}$,

- $\quad$ acid index: $<10 \mathrm{mg} \mathrm{KOH} / \mathrm{g}$,

- freezing point: $<0^{\circ} \mathrm{C}$,

- flash point (open flame): $>218^{\circ} \mathrm{C}$.

The bitumen was water foamed. The foam expansion ratio $(E R)[4,5]$ and half-life $\left(\mathrm{t}_{1 / 2}\right)[4,5]$ were determined in the second stage of the study with 9 replicates [70,71].

Physical properties of the foam were tested in a Wirtgen WLB-10S foaming plant, by applying different foaming water amounts (FWC: foaming water content): $1.5 \mathrm{wt} \%, 2.0 \mathrm{wt} \%, 2.5 \mathrm{wt} \%, 3.0 \mathrm{wt} \%$, and $3.5 \mathrm{wt} \%$, as per [4]. The bitumen foaming test was conducted under the following conditions:

- bitumen temperature: $155^{\circ} \mathrm{C}$,

- water temperature: $20^{\circ} \mathrm{C}$,

- water flow: $100 \mathrm{~g} / \mathrm{s}$,

- foaming time: $5 \mathrm{~s}$,

- air pressure: $500 \mathrm{kPa}$,

- water pressure: $600 \mathrm{kPa}$.

Results of the selected properties of the non-modified bitumen 50/70, and that modified with $0.6 \%$ SAA, are compiled in Table 1.

Foaming characteristics of the bitumen modified with $0.6 \%$ SAA are shown in Figure 1. 
Table 1. Properties of bitumen 50/70, and with $0.6 \%$ surface-active agent (SAA) content [29].

\begin{tabular}{ccccc}
\hline Property & Unit & Testing Method & \multicolumn{2}{c}{ Bitumen } \\
\cline { 4 - 5 } & & & $\mathbf{5 0 / 7 0 0}$ & $\mathbf{5 0 / 7 0 + \mathbf { 0 . 6 } \% \text { SAA }}$ \\
\hline Penetration at $25^{\circ} \mathrm{C}$ & $0.1 \mathrm{~mm}$ & PN-EN 1426 & 65.9 & 70.4 \\
Softening point $\mathrm{T}_{\mathrm{R} \& \mathrm{~B}}$ & ${ }^{\circ} \mathrm{C}$ & PN-EN 1427 & 50.4 & 48.8 \\
Fraass breaking point & ${ }^{\circ} \mathrm{C}$ & PN-EN 12593 & -15.1 & -14.2 \\
Temperature plasticity range & ${ }^{\circ} \mathrm{C}$ & - & 65.5 & 63.0 \\
Penetration Index & - & EN 12591 & -0.6 & 1.4 \\
Expansion ratio (ER) & - & - & 11 & 19 \\
Half-life $\mathrm{t}_{1 / 2}$ & $\mathrm{~S}$ & - & 10 & 21 \\
Foaming water content (FWC) & $\%$ & - & 2.5 & 2.5 \\
\hline
\end{tabular}

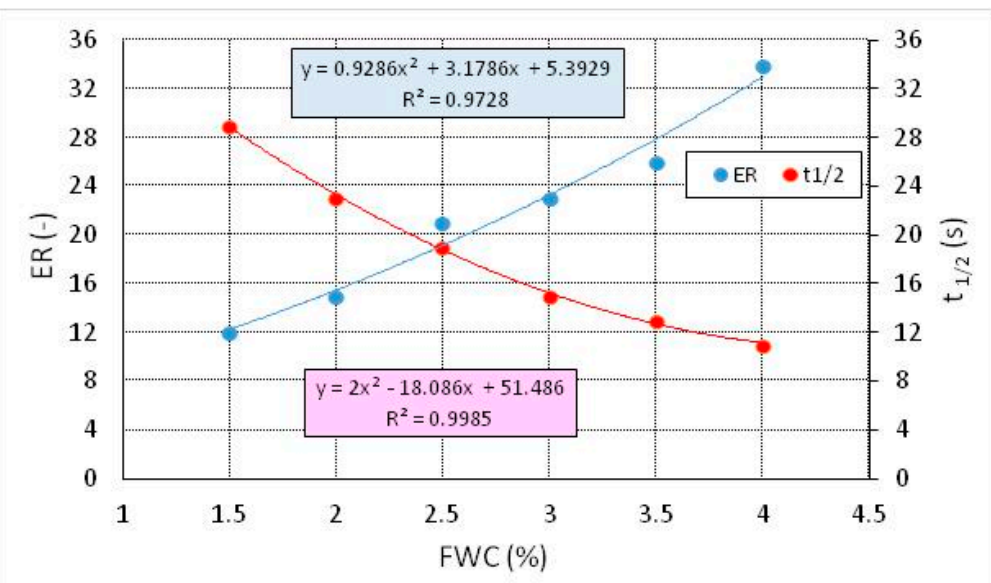

Figure 1. Foaming characteristics of bitumen 50/70 modified with $0.6 \%$ SAA [29].

The mineral mix of AC $8 \mathrm{~S}$ was designed using the aggregates commonly available in the Świętokrzyskie region: limestone filler, granulated limestone aggregate $0 / 2 \mathrm{~mm}$, and granulated gabbro aggregate $2 / 5 \mathrm{~mm}$ and $4 / 8 \mathrm{~mm}$.

The lime stone filler met all the requirements of EN 13043. The basic properties of the aggregate used in the asphalt concrete are compiled in Tables 2 and 3.

Table 2. Properties of limestone aggregates $0 / 2$.

\begin{tabular}{lccc}
\hline Property & Test & u.m. & Symbol \\
\hline Dimension d/D & EN 933-1 & - & $0 / 2$ \\
Particle size distribution & EN 933-1 & - & $\mathrm{G}_{\mathrm{F}} 85$ \\
Density & EN 1097-6 & $\mathrm{Mg} / \mathrm{m}^{3}$ & 2.73 \\
\hline
\end{tabular}

Table 3. Properties of gabbro aggregates $2 / 5$ and $4 / 8$.

\begin{tabular}{lcccc}
\hline Property & Test & u.m. & \multicolumn{2}{c}{ Symbol } \\
\hline Dimension d/D & EN 933-1 & - & $2 / 5$ & $4 / 8$ \\
Particle size distribution & EN 933-1 & - & $\mathrm{G}_{\mathrm{A}} 85$ & $\mathrm{G}_{\mathrm{A}} 85$ \\
Density & EN 1097-6 & $\mathrm{Mg} / \mathrm{m}^{3}$ & 2.98 & 2.98 \\
Shape index & EN 933-4 & $\%$ & $\mathrm{SI}_{20}$ & $\mathrm{SI}_{15}$ \\
Flakiness index & EN 933-3 & $\%$ & $\mathrm{FI}_{20}$ & $\mathrm{FI}_{15}$ \\
Percentage of crushed and broken surfaces & EN 933-5 & $\%$ & $\mathrm{C}_{90 / 3}$ & $\mathrm{C}_{100 / 0}$ \\
Frost resistance & EN 1367-1 & $\%$ & $\mathrm{~F}_{1}$ & $\mathrm{~F}_{1}$ \\
Abrasion resistance & EN1097-1 & $\%$ & - & $\mathrm{M}_{\mathrm{DE}} 15$ \\
Resistance to fragmentation & EN 1097-2 & $\%$ & - & $\mathrm{LA}_{15}$ \\
\hline
\end{tabular}


The hydrated lime used in the tests met the requirements of EN-459-1 CL 90-s.

\subsection{Mix Design and Sample Preparation}

Bitumen $50 / 70$ modified with $0.6 \%$ SAA is characterized by very high values of foaming parameters [25]. Thus, its use in the production of bituminous mixtures should ensure a very good coating of aggregate by the binder.

The basic frame-compositions of the mineral mixture and bituminous mixture are summarized in Table 4 and the particle size design of AC $8 \mathrm{~S}$ is plotted in Figure 2 [68,72].

Table 4. Composition of AC 8 mineral mixture [72].

\begin{tabular}{ccc}
\hline Materials & $\begin{array}{c}\text { Mineral Mixture } \\
\mathbf{( \% ~} \mathbf{~ m} / \mathbf{m})\end{array}$ & $\begin{array}{c}\text { Bituminous Mixture } \\
\mathbf{( \% ~} \mathbf{~ m} / \mathbf{m})\end{array}$ \\
\hline Filler (limestone aggregate) & 7.0 & 6.6 \\
Crushed fine continuously graded aggregate 0/2 mm (limestone) & 37.0 & 34.8 \\
Coarse aggregate 2/5 mm (gabbro) & 16.0 & 15.1 \\
Coarse aggregate 4/8 mm (gabbro) & 40.0 & 37.7 \\
50/70 penetration paving-grade bitumen & - & 5.6 \\
Total & 100.0 & 100.0 \\
\hline
\end{tabular}

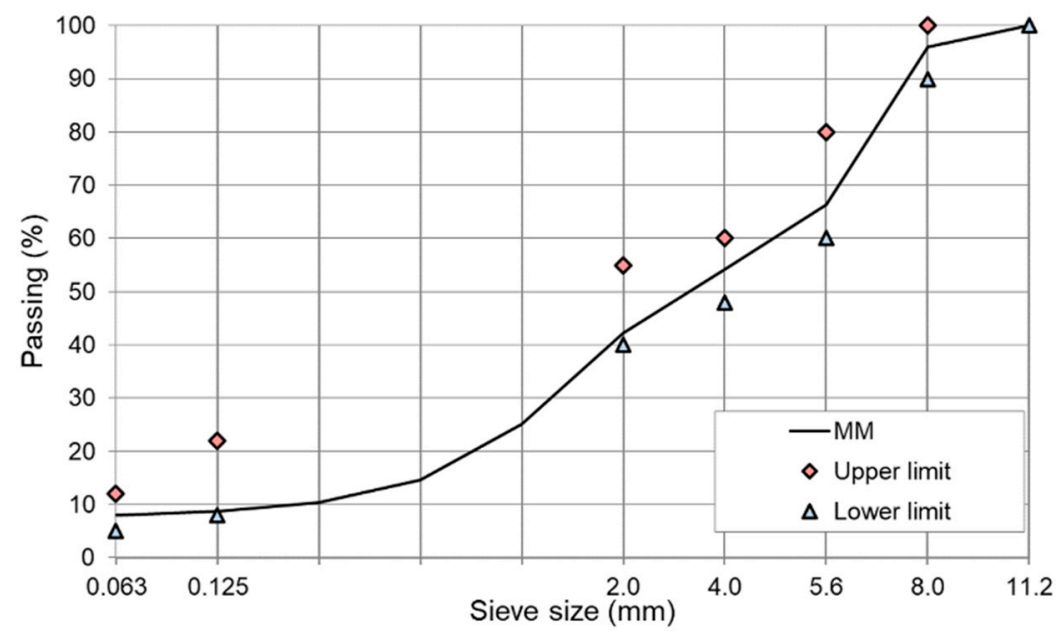

Figure 2. Grading curve of AC 8 mineral mixture with limiting points as in WT-2 2014 requirements [68].

A variable bitumen amount was used in this study to determine its effect, in terms of hydrated lime dosing, on asphalt concrete properties. The grading of the aggregate mix was corrected while increasing the amount of foamed bitumen to $5.6 \%$ and $6.5 \%$, according to the experimental design.

In order to ensure the required value of asphalt concrete parameters, hydrated lime was dosed at $15 \%, 30 \%$, and $45 \%$ by weight as a replacement for an equivalent amount of lime filler.

The AC $8 \mathrm{~S}$ mixture was made in a heated mechanical mixer, to which foamed bitumen produced in the WLB-10S device was added. The production temperature of AC $8 \mathrm{~S}$ with additives did not exceed $100{ }^{\circ} \mathrm{C}$.

The experimental design parameters of the AC $8 \mathrm{~S}$ were determined based on the assumed $4 \times 4$ factorial design, following the adopted research program (Figure 3). 


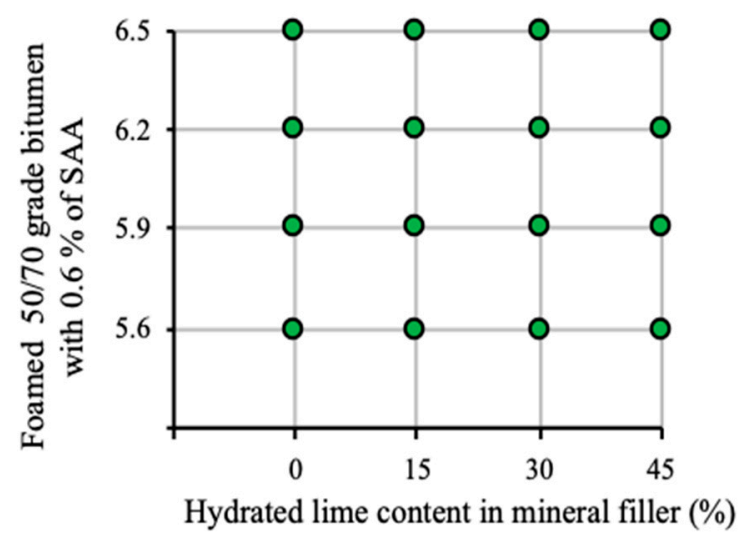

Figure 3. Experimental design [72].

\subsection{Testing}

This study aimed to determine the effect of hydrated lime on the properties of HWMA concrete with foamed bitumen, through the evaluation of the following parameters, and following the test procedures set out in the technical requirements of WT-2 2014 [68] and EN 13108-1,

- $\quad$ air void content $\left(\mathrm{V}_{\mathrm{a}}, \%\right)$ as per EN 12697-8,

- indirect tensile stiffness modulus at $-10{ }^{\circ} \mathrm{C}, 0{ }^{\circ} \mathrm{C},+10{ }^{\circ} \mathrm{C},+20{ }^{\circ} \mathrm{C},+30{ }^{\circ} \mathrm{C}\left(\mathrm{S}_{\mathrm{m}}, \mathrm{MPa}\right)$, as per EN 12697-26,

- $\quad$ resistance to permanent deformation (WTS AIR, $_{\text {PRD }}$ AIR), as per EN 12697-22.

Parameters $\mathrm{V}_{\mathrm{a}}$, and $\mathrm{S}_{\mathrm{m}}$ were determined by compacting the specimens with a Marshall hammer, and using the number of blows as specified for each procedure used. The specimens (slabs) for testing the resistance to permanent deformation, parameters $W_{T S} S_{\text {AIR }}$ and PRD $_{\mathrm{AIR}}$, were prepared with a dedicated compactor, as per EN 12697-22. The asphalt concrete (AC) specimens used met the assumed requirements, in terms of physical and geometrical characteristics.

\subsubsection{Air Void Content $\left(\mathrm{V}_{\mathrm{a}}\right)$}

The properties of asphalt concrete largely depend on air void content. An excessively high content of air voids adversely affects AC resistance to moisture and frost, and its performance under heavy loads. On the other hand, the insufficient content of air voids worsens the resistance of the bituminous mixture to permanent deformation, despite having a positive effect on moisture and frost resistance.

The percentage of air voids was calculated in accordance with EN 12697-8: 2005 on the basis of the following relationship

$$
\mathrm{V}_{\mathrm{a}}=\frac{\rho_{\mathrm{m}}-\rho_{\mathrm{b}}}{\rho_{\mathrm{m}}} 100 \%
$$

where: $\mathrm{V}_{\mathrm{a}}$ is the air void content in the bituminous mixture (volume \%); $\rho_{\mathrm{m}}$ is the theoretical maximum density of mixture $\left(\mathrm{kg} / \mathrm{m}^{3}\right) ; \rho_{\mathrm{b}}$ is the bulk density of compacted mixture $\left(\mathrm{kg} / \mathrm{m}^{3}\right)$.

\subsubsection{Indirect Tensile Stiffness Modulus $\left(\mathrm{S}_{\mathrm{m}}\right)$}

The stiffness modulus of asphalt concrete $S_{m}$ is a very important parameter, used for predicting AC behavior under different climatic conditions. In the range of winter negative temperatures, an increase in its value may indicate that the asphalt concrete is too rigid, which leads to the development of cracks and, consequently, to the destruction of the asphalt pavement. However, in the range of increasing summer temperatures, the parameter should reach the highest values, then the pavement will be resistant to permanent deformation. Stiffness modulus tests were performed at $-10^{\circ} \mathrm{C}, 0^{\circ} \mathrm{C}, 10^{\circ} \mathrm{C}$, $20^{\circ} \mathrm{C}$, and $30^{\circ} \mathrm{C}$, corresponding to the average temperature of the winter period, spring transition period, the beginning of spring, the beginning of summer, and the average summer temperature. 
The stiffness modulus was determined with the standard load pulse applied to the specimen surface, following the procedure outlined in EN 12697-26 (Figure 4).

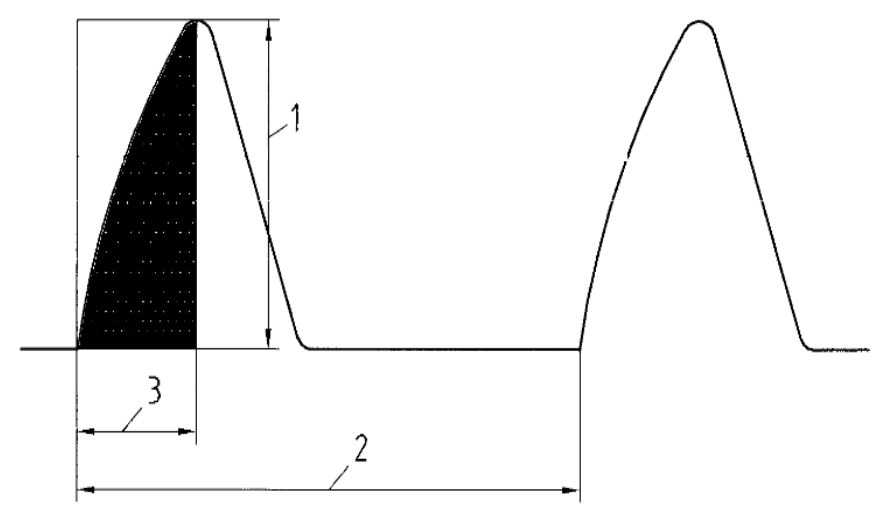

(a)

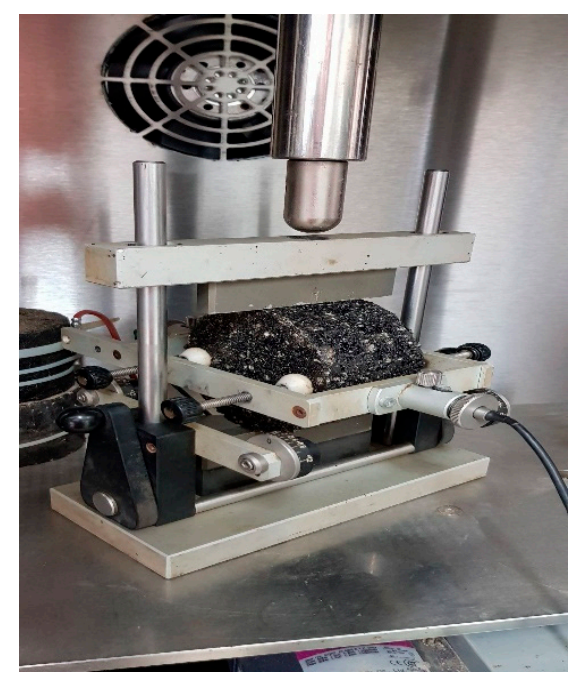

(b)

Figure 4. An example of a force applied to the specimen and the loading scheme [71]: (a) loading pulse form (1: maximum loading, 2: periodical force pulse, 3: force increase time), (b) set-up for indirect tensile stiffness modulus test; laboratory at Kielce University of Technology, (source: M. M. Iwański).

The test temperature of the mixture after the conditioning period was determined, with an accuracy of $\pm 0.5^{\circ} \mathrm{C}$. To ensure the correct performance of the test, before the test, the appropriate value of Poisson's ratio (dependent on the temperature and loading time) was entered into the calculation program. During the test, the load factor was read, and if it was 0.6 , the test was correct.

The values of the stiffness modulus and Poisson's ratio were determined from the following formulas:

$$
\begin{aligned}
& \mathrm{S}_{\mathrm{m}}=\frac{\mathrm{F} \cdot(\mathrm{v}+0.27)}{\mathrm{z} \cdot \mathrm{h}} \\
& \mathrm{v}=3.59 \cdot \frac{\mathrm{z}}{\Delta \mathrm{V}}-0.27
\end{aligned}
$$

where:

$\mathrm{S}_{\mathrm{m}}$ is the indirect tensile stiffness modulus [MPa],

$\mathrm{F}$ is the maximum force applied to the specimen [N],

$\checkmark$ is the temperature-dependent Poisson's ratio,

$\mathrm{z}$ is the horizontal displacement amplitude for the specimen under loading [mm],

$\mathrm{h}$ is the specimen thickness [mm],

$\Delta \mathrm{V}$ is the maximum vertical displacement of the specimen (corresponding to maximum horizontal displacement) (mm).

Analysis of Equation (3) indicates that the increase in transverse strain and the specimen thickness contribute to the lowering of internal stresses in the pavement, and thus to the $S_{m}$ reduction.

When the load factor was not 0.6 , the stiffness modulus of the mixture was calculated using the following formula:

$$
\mathrm{S}_{\mathrm{m}}{ }^{\prime}=\mathrm{S}_{\mathrm{m}} \cdot\left[1-0.322 \cdot\left(\log \left(\mathrm{S}_{\mathrm{m}}\right)-1.82\right) \cdot(0.60-\mathrm{k})\right]
$$

where:

$\mathrm{S}_{\mathrm{m}}$ ' is the stiffness modulus with the load factor accounted for [MPa],

$\mathrm{k}$ is the value of the load factor. 


\subsubsection{Resistance to Permanent Deformation}

Resistance to permanent deformation of the asphalt concrete was assessed to EN 12697-22. The test was carried out in air, in a small wheel tracking device, using rectangular prisms $400 \mathrm{~mm} \times 300 \mathrm{~mm}$ and $40 \mathrm{~mm}$ thick, as outlined in WT-2 2014 [68]. The specimen mass varied with the density value obtained in the Marshall tests performed earlier. The testing procedure consisted of placing the specimen in a steel mold, and mounting it on a movable tray. After a 6 -h conditioning period, starting from the moment the device reached the temperature of $60 \pm 1{ }^{\circ} \mathrm{C}$, the specimens were subjected to a load of $700 \pm 10 \mathrm{~N}$, using a wheel $200 \mathrm{~mm}$ in diameter with a tire $50 \pm 1 \mathrm{~mm}$ in width, which tracked on the specimen along a length of $230 \mathrm{~mm} \pm 10 \mathrm{~mm}$. Rut depth was measured continuously on the specimen. The test wheel travelled 26.5 cycles per $60 \mathrm{~s}$. The test was continued to reach 10,000 cycles. Results

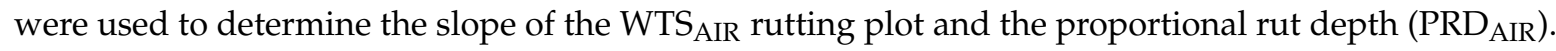
The proportional rut depth and the maximum rut depth gain were calculated from:

$$
\begin{gathered}
\mathrm{PRD}_{\text {AIR }}=\frac{\mathrm{RD}_{\text {AIR }}}{\mathrm{h}} \cdot 100 \% \\
\mathrm{WTS}_{\mathrm{AIR}}=\frac{\left(\mathrm{d}_{10000}-\mathrm{d}_{5000)}\right)}{5}[\mathrm{~mm} / 10000 \text { cycles }]
\end{gathered}
$$

where:

$\mathrm{RD}_{\mathrm{AIR}}$ is the rut depth $(\mathrm{mm})$,

$\mathrm{d}_{10000}$ is the rut depth after 10,000 cycles $(\mathrm{mm})$,

$\mathrm{d}_{5000}$ is the rut depth after 5000 cycles $(\mathrm{mm})$,

$\mathrm{h}$ is the specimen height $(\mathrm{mm})$.

For further analyses, the arithmetic mean of nine tests was taken as the final result of AC resistance to permanent deformation.

\subsubsection{Statistical Analysis of Test Results}

The obtained test results were subjected to statistical analysis of variance (ANOVA), the purpose of which was to determine the significance of the impact of the given factor (hydrated lime, $H L$, foamed bitumen, $F B$ ) on the properties of the bituminous mixture [73,74].

The amounts of foamed bitumen and hydrated lime were assumed to be significant factors affecting the analyzed AC property when the $p$-value characterizing them was less than the assumed significance level $\alpha=0.05$.

The change in the value of the tested parameter (A) in asphalt concrete AC $8 \mathrm{~S}$, relative to the contents of foamed bitumen 50/70 with $0.6 \%$ SAA and hydrated lime, was comprehensively described with a statistical model using the second-degree polynomial [73]:

$$
y=b_{0}+\sum_{i=1}^{n} b_{i} \cdot x_{i}+\sum_{i=j=1}^{n} b_{i=j} \cdot x_{i} \cdot x_{j}+\sum_{i=1}^{n} b_{i i} \cdot x_{i}^{2}
$$

which in the performed analysis takes the form:

$$
A=b_{0}+b_{1} \cdot x_{1}+b_{2} \cdot x_{2}+b_{3} \cdot x_{1} \cdot x_{2}+b_{4} \cdot x_{1}{ }^{2}+b_{5} \cdot x_{2}{ }^{2}
$$

where $\mathrm{x}_{1}=$ foamed bitumen $(F B)(\%), \mathrm{x}_{2}=$ hydrated lime $(H L)(\%), \mathrm{b}_{0}-\mathrm{b}_{5}$ are regression coefficients. 


\section{Results and Discussion}

\subsection{The Effects of Foamed Bitumen and Hydrated Lime on Air Void Content in Asphalt Concrete}

Proper performance of the asphalt concrete in the pavement, and its durability, are secured when the air void content in the HWMA concrete is close to or more advantageous than that of the HMA concrete.

The air void content in AC $8 \mathrm{~S}$ was determined in accordance with the methodology set forth in EN 12697-6:2008. Asphalt concrete AC 8 S should have 2.0\% to 4.0\% air voids [68,69,72]. Each test series consisted of nine trials, the number of which was determined in accordance with [70,71]. The homogeneity of the results was confirmed by the coefficient of variation ranging from $3.36 \%$ to $7.77 \%$. The ANOVA test showed that the content of foamed bitumen and hydrated lime was a significant factor that affected the quantity of air voids in AC $8 \mathrm{~S}$, because the $p$-value was lower than the significance level $\alpha=0.05$. It was also found that there were interactions between the amount of foamed bitumen and hydrated lime, which influenced the air void content in the mixture ( $p$-value less than $\alpha=0.05)$.

A graphical representation of the data is shown in Figure 5.

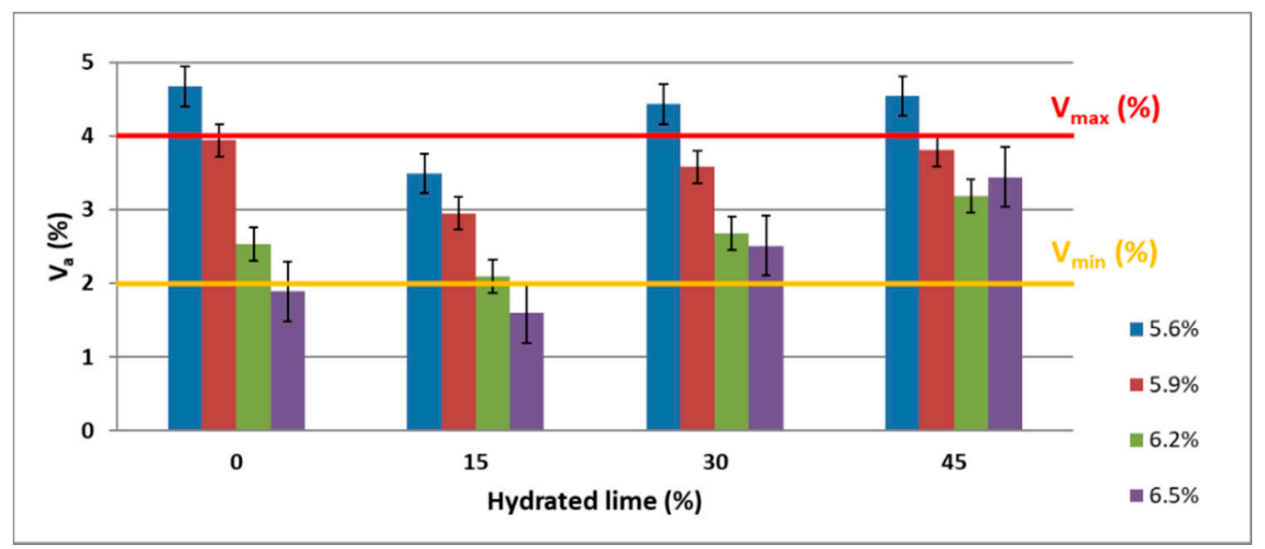

Figure 5. Air void content in AC $8 \mathrm{~S}$ as a function of the content of hydrated lime $(0 \%, 15 \%, 30 \%, 45 \%)$ and foamed bitumen modified with $0.6 \%$ SAA $(5.6 \%, 5.9 \%, 6.2 \%, 6.5 \%)$.

Analysis of the test results in Figure 5 leads to the conclusion that the content of both the foamed bitumen and the hydrated lime substantially affect the percentage content of air voids in AC 8 S. As the amount of foam bitumen increases to $6.5 \%$, the air void content decreases, regardless of the hydrated lime quantity added. The use of hydrated lime at $15 \%$, in place of a portion of limestone dust, alters this parameter considerably. The amount of air is reduced, which is certainly the effect of improving the adhesion between the bitumen and mineral mixture. The $30 \%$ and $45 \% \mathrm{~m} / \mathrm{m}$ content of hydrated lime in place of limestone dust increases the air void content, regardless of the amount of foamed bitumen used in the asphalt concrete. This may be related to an insufficient amount of the binder, being the result of the use of hydrated lime, which has a larger specific surface area than limestone dust. As a result of the "deficiency" of the required amount of the binder, the mixture becomes difficult to compact to the proper level, and the air void content increases [32]. Regardless of the hydrated lime content, the smallest amount of air voids is found in AC $8 \mathrm{~S}$ containing $6.5 \%$ foamed bitumen. A high binder content, however, may cause it to fail to maintain adequate resistance to permanent deformation [30,31].

A comprehensive analysis of the air void content variation, with respect to the amount of hydrated lime and foamed bitumen 50/70 modified with $0.6 \%$ SAA, was presented using a statistical model [74].

Table 5 compiles the values describing the parameters of the regression model for the relationships between the air void content in AC $8 \mathrm{~S}$ and the content of SAA modified foamed bitumen and hydrated lime. 
Table 5. Parameters of the model describing the relationships between $\mathrm{V}_{\mathrm{a}}$ of AC $8 \mathrm{~S}$ and the contents of foamed bitumen with $0.6 \%$ SAA and hydrated lime.

\begin{tabular}{lccccc}
\hline \multicolumn{1}{c}{ Effect } & Regression Coeff. & SE & $p$-Value & $\begin{array}{c}\mathbf{- 9 5 \%} \\
\text { Cnf. Lmt }\end{array}$ & $\begin{array}{c}\mathbf{+ 9 5 \%} \\
\text { Cnf. Lmt }\end{array}$ \\
\hline & Variable: $\mathrm{V}_{\mathrm{a}}(\%), \mathrm{R}^{2}=0.880 ; \mathrm{R}^{2}$ adj. $=0.875$ & & \\
\hline Intercept & 68.159 & 6.791 & $<0.001$ & 54.720 & 81.596 \\
(1) Foamed bitumen (\%)(L) & -18.425 & 2.247 & $<0.001$ & -22.872 & -1.978 \\
Foamed bitumen (\%)(Q) & 1.266 & 0.185 & $<0.001$ & 0.898 & 1.6334 \\
(2) Hydrated lime (\%)(L) & -0.276 & 0.018 & $<0.001$ & -0.13 & -0.241 \\
Hydrated lime (\%)(Q) & 0.001 & 0.001 & $<0.001$ & $<0.001$ & $<0.001$ \\
1 L * L & 0.038 & 0.003 & $<0.001$ & 0.032 & 0.044 \\
\hline
\end{tabular}

where $\mathrm{Q}=$ quadratic, $\mathrm{L}=$ linear.

Analysis of the results (Table 5) indicates that both the quantity of foamed bitumen 50/70 and hydrated lime, as well as the interaction between these factors, have a substantial impact on the air void content in the asphalt concrete. A synergistic effect of the hydrated lime and foamed bitumen containing $0.6 \%$ SAA occurs in the asphalt concrete. The model of the analyzed relationships was adopted correctly because the adjusted coefficient of determination $\left(R^{2}\right)$ was $88 \%$.

The impact of hydrated lime and foamed asphalt on the content of air voids $\left(\mathrm{V}_{\mathrm{a}}\right)$ in AC $8 \mathrm{~S}$ for the developed model is shown in Figure 6.

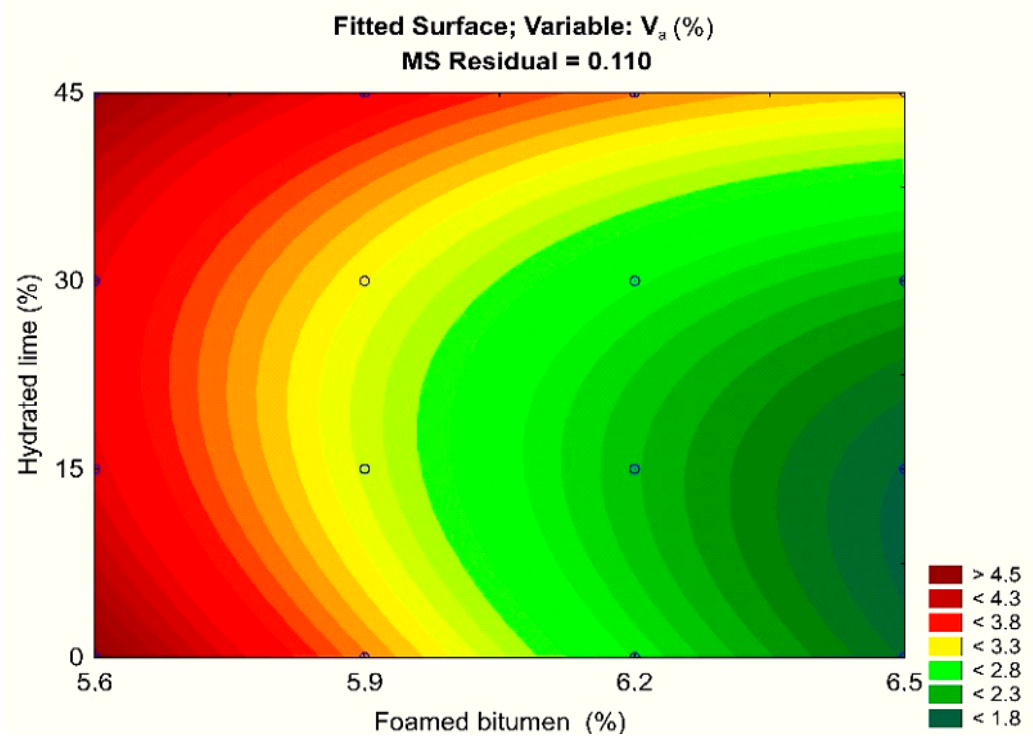

Figure 6. Air void content $\left(\mathrm{V}_{\mathrm{a}}\right)$ of $\mathrm{AC} 8 \mathrm{~S}$ as a function of the quantity of foamed bitumen and hydrated lime; the model describing these relationships $\mathrm{V}_{\mathrm{a}}=68.158-18.425 \mathrm{FB}+1.266 \mathrm{FB}^{2}-0.276 \mathrm{HL}+0.001 \mathrm{HL}^{2}$ +0.038 FB·HL [74].

The test results obtained show that, throughout the entire scope of the experiment, increasing the content of foamed bitumen and hydrated lime reduced the content of air voids in the asphalt concrete. At the same time, the hydrated lime had a significant effect on the assessed parameter; in the range from $5.6 \%$ to $5.9 \%$ of the foamed bitumen, it increased the air void content over the maximum recommended value of $4.0 \%$. The increase in the foamed bitumen content in the range from $5.9 \%$ to $6.2 \%$, at the hydrated lime content of $15 \%$ to $30 \%$, allowed the parameter to achieve the recommended values [68]. A further increase in the foamed bitumen content up to $6.5 \%$ reduced the quantity of air voids below the required $4.0 \%$ [68]. 


\subsection{Effect of Foamed Bitumen and Hydrated Lime on Asphalt Concrete Stiffness Modulus}

A universal testing machine UTM-25 was employed to determine the stiffness modulus $S_{m}$ of the asphalt concrete AC $8 \mathrm{~S}$. Both the specimens and the accessories of the test device were placed in a thermostatic chamber prior to testing, as required by EN 12697-26. Each series of test specimens consisted of nine samples, the number of which was determined according to [70,71]. The results were characterized by high repeatability, as the coefficient of variation was between $2.17 \%$ and $8.80 \%$ throughout the entire experiment.

The results of stiffness modulus $\mathrm{S}_{\mathrm{m}}$ testing at various test temperatures $\left(-10^{\circ} \mathrm{C}, 0^{\circ} \mathrm{C}, 10^{\circ} \mathrm{C}, 20^{\circ} \mathrm{C}\right.$, and $30^{\circ} \mathrm{C}$ ) are shown in Figure 7.

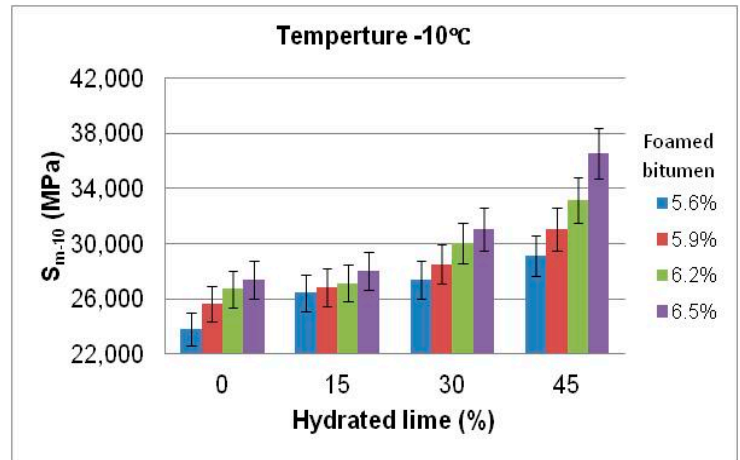

(a)

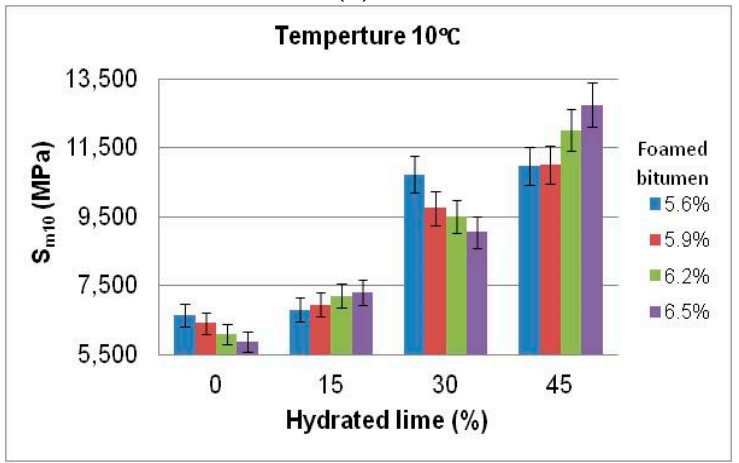

(c)

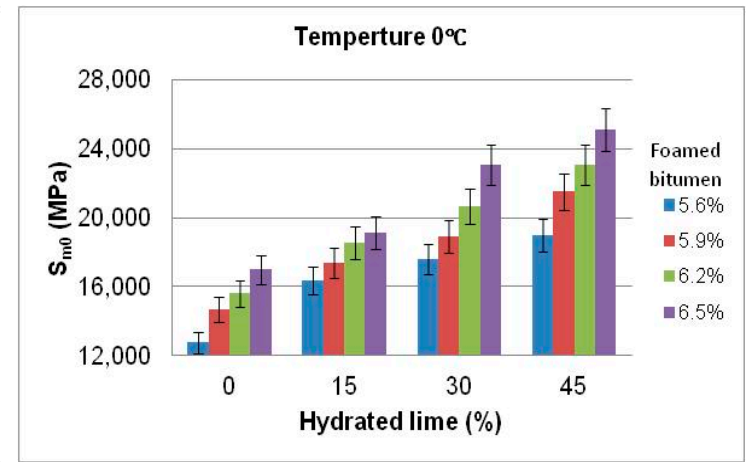

(b)

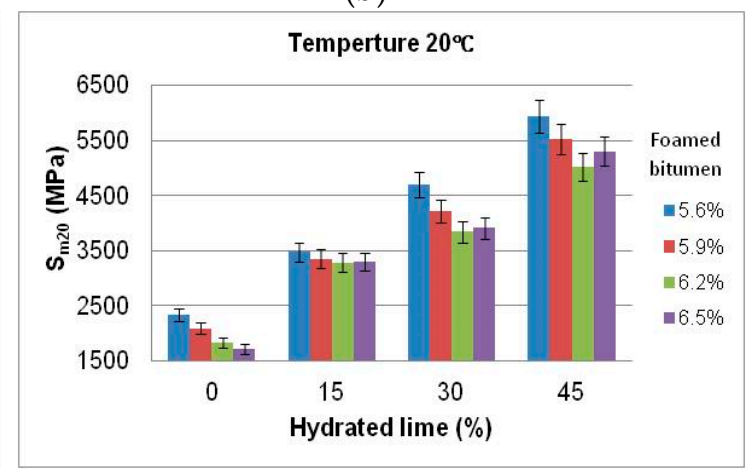

(d)

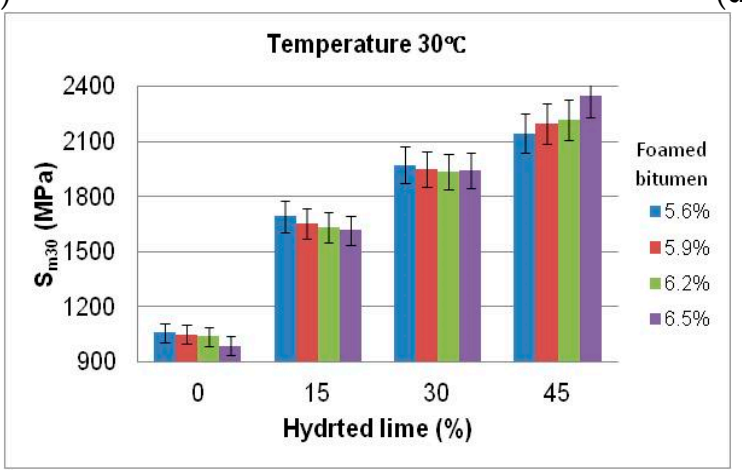

(e)

Figure 7. Stiffness modulus $\left(\mathrm{S}_{\mathrm{m}}\right)$ (IT-CY) of asphalt concrete AC $8 \mathrm{~S}$, as a function of the contents of foamed bitumen and hydrated lime at various test temperatures, $S_{m-10}(\mathbf{a}), S_{m 0}(b), S_{m+10}(\mathbf{c}), S_{m 20}(d)$, $\mathrm{S}_{\mathrm{m} 30}(\mathbf{e})$

The test results show that the content of hydrated lime has a significant effect on the stiffness modulus $\mathrm{S}_{\mathrm{m}}$ of asphalt concrete AC $8 \mathrm{~S}$ at temperatures from $-10{ }^{\circ} \mathrm{C}$ to $30^{\circ} \mathrm{C}$. The extent of this effect depends on the content of foamed bitumen. Test temperature also influences the value of this 
parameter. In the temperature range $-10^{\circ} \mathrm{C}$ to $0^{\circ} \mathrm{C}$, the influence of hydrated lime and foam bitumen is the same. Increasing the amount of both components causes the stiffness modulus to increase. Nevertheless, the effect of hydrated lime is more significant than that of the binder.

When increased from $10{ }^{\circ} \mathrm{C}$ to $20{ }^{\circ} \mathrm{C}$, the test temperature alters the nature of the interaction between hydrated lime and foamed bitumen. The effect of the binder becomes more important, although hydrated lime also plays a significant role.

A further increase in the test temperature up to $30{ }^{\circ} \mathrm{C}$ enhances the effect of hydrated lime on the modulus, while the amount of bitumen remains less significant. The observed relationship is very important, because it means that by substantially increasing the stiffness modulus, the hydrated lime provides asphalt concrete with greater resistance to permanent deformation.

The most beneficial effect of hydrated lime on the stiffness modulus of HWMA concrete AC $8 \mathrm{~S}$, in the test temperature range from $-10{ }^{\circ} \mathrm{C}$ to $+30^{\circ} \mathrm{C}$, can be observed for the HL content from $15 \%$ to $30 \%$, and foamed bitumen content from 5.9\% to 6.2\%. Proper performance of asphalt concrete AC $8 \mathrm{~S}$ in the structural layer of the pavement will be ensured, both in winter (no cracks) and in summer (resistance to permanent deformation).

A second-degree polynomial model was adopted to comprehensively describe the relationship between the stiffness modulus $\left(S_{m}\right)$ of HWMA concrete AC $8 \mathrm{~S}$ (foamed bitumen 50/70 modified with $0.6 \%$ SAA; hydrated lime) and the test temperature. The model was assessed with the analysis of variance (ANOVA) [73,74].

Analysis of the parameters indicates that the amount of foamed bitumen and hydrated lime is a significant factor that affects the stiffness modulus $\left(S_{m}\right)$ of the asphalt concrete AC $8 \mathrm{~S}$, because the levels of $p$-value related to them are lower than the assumed significance level $\alpha=0.05$. The intensity of this effect relies on the test temperature, and is most pronounced at temperatures $-10{ }^{\circ} \mathrm{C}, 20{ }^{\circ} \mathrm{C}$, and $30^{\circ} \mathrm{C}$. Please note the significant role of the interactions between foamed bitumen and hydrated lime. The interactions affect the value of the parameter (the $p$-value is less than $\alpha=0.05$ ), thereby confirming the synergy between these two factors. This effect supports the assumption about the desirability of using both the foamed bitumen and the hydrated lime in asphalt concrete.

The value of the adjusted coefficient of determination $\left(\mathrm{R}^{2}\right)$ ranges from $81 \%$ to $94 \%$, depending on the stiffness modulus and the test temperature applied. The $\mathrm{R}^{2}$ values indicate the correctness of the adopted models for describing the relationships between the stiffness modulus $\left(S_{m}\right)$ of the asphalt concrete AC 8 S, and the amount of foamed bitumen and hydrated lime.

The parameters of the regression model for the relationship between the $S_{m}$ and the amount of hydrated lime and foamed bitumen are summarized in Table 6. 
Table 6. Stiffness modulus $\left(\mathrm{S}_{\mathrm{m}}\right)$ of the HWMA concrete, as a function of test temperature and the amount of foamed bitumen and hydrated lime.

\begin{tabular}{|c|c|c|c|c|c|}
\hline Effect & Regression Coeff. & SE & $p$-Value & $\begin{array}{c}-95 \% \text { Cnf. } \\
\text { Lmt }\end{array}$ & $\begin{array}{c}+95 \% \text { Cnf. } \\
\text { Lmt }\end{array}$ \\
\hline \multicolumn{6}{|c|}{ Variable: $S_{\mathrm{m}-10}(\mathrm{MPa}), \mathrm{R}^{2}=0.8187 ; \mathrm{R}^{2}$ adj $=0.8122$, Pure Error $\mathrm{MS}=1,809,712$} \\
\hline Intercept & $31,976.28$ & $45,578.49$ & 0.4842 & $-58,208.5$ & $122,161.1$ \\
\hline (1) Foamed bitumen (\%)(L) & -4250.82 & $15,082.22$ & 0.7785 & $-34,093.6$ & $25,591.9$ \\
\hline Foamed bitumen $(\%)(Q)$ & 535.14 & 1245.61 & 0.6682 & -1929.5 & 2999.8 \\
\hline (2) Hydrated Lime $(\%)(\mathrm{L})$ & -560.66 & 122.82 & $<0.001$ & -803.7 & -317.6 \\
\hline Hydrated Lime $(\%)(\mathrm{Q})$ & 2.21 & 0.50 & $<0.001$ & 1.2 & 3.2 \\
\hline $1 \mathrm{~L} \times 2 \mathrm{~L}$ & 100.37 & 19.93 & $<0.001$ & 60.9 & 139.8 \\
\hline \multicolumn{6}{|c|}{ Variable: $S_{\mathrm{m} 0}(\mathrm{MPa}) ; \mathrm{R}^{2}=0.8567 ; \mathrm{R}^{2}$ adj $=0.8512 ;$ Pure Error $=1743,61$} \\
\hline Intercept & $-14,876.7$ & $44,742.85$ & 0.7401 & $-103,408$ & $73,654.63$ \\
\hline (1) Foamed bitumen (\%)(L) & 6178.5 & $14,805.70$ & 0.6771 & $-23,117$ & $35,474.09$ \\
\hline Foamed bitumen $(\%)(Q)$ & -203.2 & 1222.77 & 0.8683 & -2623 & 2216.31 \\
\hline (2) Hydrated Lime (\%)(L) & -178.1 & 120.57 & 0.1422 & -417 & 60.52 \\
\hline Hydrated Lime $(\%)(Q)$ & -0.8 & 0.49 & 0.1111 & -2 & 0.18 \\
\hline $1 \mathrm{~L} \times 2 \mathrm{~L}$ & 61.4 & 19.56 & $<0.001$ & 23 & 100.06 \\
\hline \multicolumn{6}{|c|}{ Variable: $S_{\mathrm{m} 10}(\mathrm{MPa}) ; \mathrm{R}^{2}=0.8714, \mathrm{R}^{2}$ adj $=0.8667$, Pure Error $\mathrm{MS}=45,0536.1$} \\
\hline & $42,843.7$ & $22,741.54$ & 0.0618 & $-2,154.3$ & $87,841.71$ \\
\hline (1) Foamed bitumen (\%)(L) & $-11,206.5$ & 7525.32 & 0.1389 & $-26,096.6$ & 3683.69 \\
\hline Foamed bitumen $(\%)(\mathrm{Q})$ & 846.5 & 621.50 & 0.1756 & -383.3 & 2076.24 \\
\hline (2) Hydrated Lime (\%)(L) & -194.2 & 61.28 & $<0.001$ & -315.4 & -72.92 \\
\hline Hydrated Lime (\%)(Q) & 1.2 & 0.25 & $<0.001$ & 0.8 & 1.74 \\
\hline $1 \mathrm{~L} \times 2 \mathrm{~L}$ & 43.8 & 9.94 & $<0.001$ & 24.1 & 63.43 \\
\hline \multicolumn{6}{|c|}{ Variable: $S_{\mathrm{m} 20}(\mathrm{MPa}) ; \mathrm{R}^{2}=0.9434 ; \mathrm{R}^{2}$ adj $=0.946 ;$ Pure Error $\mathrm{MS}=79,096.06$} \\
\hline Intercept & $44,108.5$ & 9528.677 & $<0.001$ & $25,254.4$ & $62,962.65$ \\
\hline (1) Foamed bitumen (\%)(L) & $-13,433.1$ & 3153.101 & $<0.001$ & $-19,672.1$ & -7194.16 \\
\hline Foamed bitumen $(\%)(\mathrm{Q})$ & 1068.0 & 260.408 & $<0.001$ & 552.7 & 1583.2 \\
\hline (2) Hydrated Lime (\%)(L) & 117.0 & 25.678 & $<0.001$ & 66.2 & 167.82 \\
\hline Hydrated Lime (\%)(Q) & -0.1 & 0.104 & 0.3932 & -0.3 & 0.12 \\
\hline $1 \mathrm{~L} \times 2 \mathrm{~L}$ & -6.4 & 4.167 & 0.1282 & -14.6 & 1.86 \\
\hline \multicolumn{6}{|c|}{ Variable: $S_{\mathrm{m} 30}(\mathrm{MPa}) ; \mathrm{R}^{2}=0.9285, \mathrm{R}^{2}$ adj $=0.9259$, Pure Error $\mathrm{MS}=15,126.99$} \\
\hline Intercept & 4073.402 & 4167.076 & 0.3303 & -4171.87 & $12,318.67$ \\
\hline (1) Foamed bitumen (\%)(L) & -872.150 & 1378.912 & 0.5282 & -3600.56 & 1856.26 \\
\hline Foamed bitumen $(\%)(Q)$ & 61.340 & 113.881 & 0.5911 & -163.99 & 286.67 \\
\hline (2) Hydrated Lime (\%)(L) & 6.551 & 11.229 & 0.5606 & -15.67 & 28.77 \\
\hline Hydrated Lime (\%)(Q) & -0.376 & 0.046 & $<0.001$ & -0.47 & -0.29 \\
\hline $1 \mathrm{~L} \times 2 \mathrm{~L}$ & 5.991 & 1.822 & $<0.001$ & 2.39 & 9.60 \\
\hline
\end{tabular}

Analysis of the parameters compiled in Table 5 confirms the significance of hydrated lime in affecting the stiffness modulus $\left(\mathrm{S}_{\mathrm{m}}\right)$ of AC $8 \mathrm{~S}$, because the levels of $p$-value are lower than the assumed significance level $\alpha=0.05$. It is important to note, the interaction between the foamed bitumen and hydrated lime for the stiffness modulus, $\mathrm{S}_{\mathrm{m}-10}$ and $\mathrm{S}_{\mathrm{m} 10}$ (the $p$-value is less than $\alpha=0.05$ ).

The value of the adjusted coefficient of determination $\left(\mathrm{R}^{2}\right)$ reaches nearly $81 \%, 85 \%, 87 \%, 94 \%$, and $93 \%$, respectively, at temperatures $-10{ }^{\circ} \mathrm{C}, 0{ }^{\circ} \mathrm{C}, 10{ }^{\circ} \mathrm{C}, 20^{\circ} \mathrm{C}$, and $30^{\circ} \mathrm{C}$, which indicates a high reliability of the adopted models for describing the stiffness modulus $\left(\mathrm{S}_{\mathrm{m}}\right)$ against the amount of foamed bitumen and hydrated lime (Figure 8). 


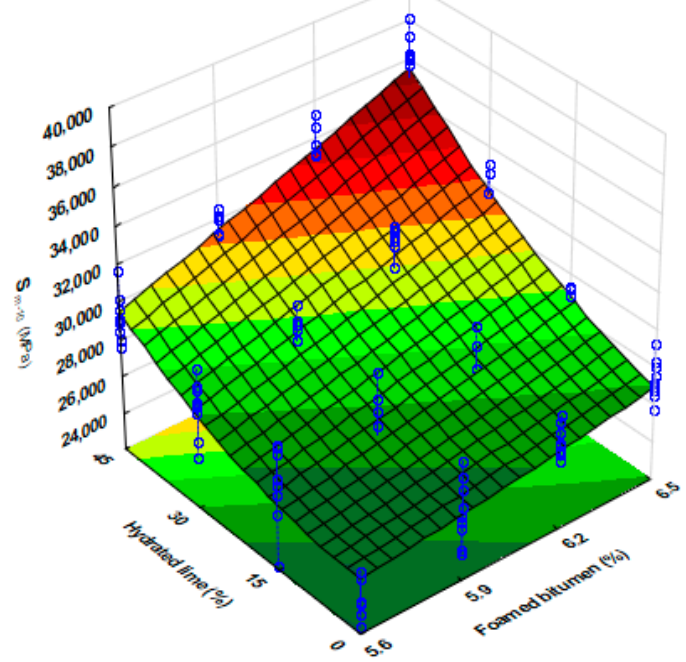

(a)

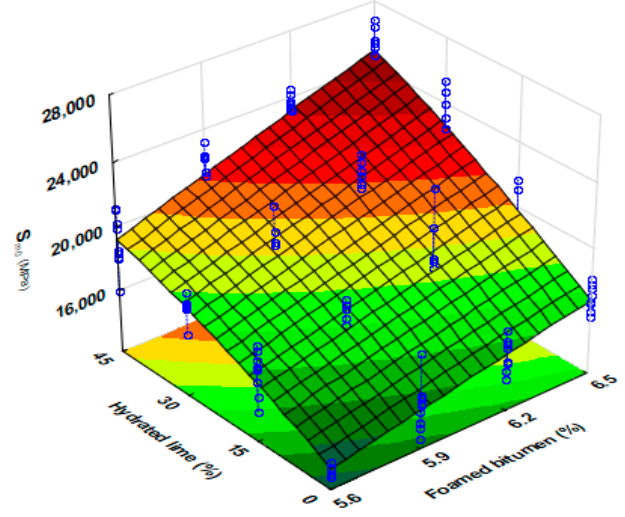

(b)
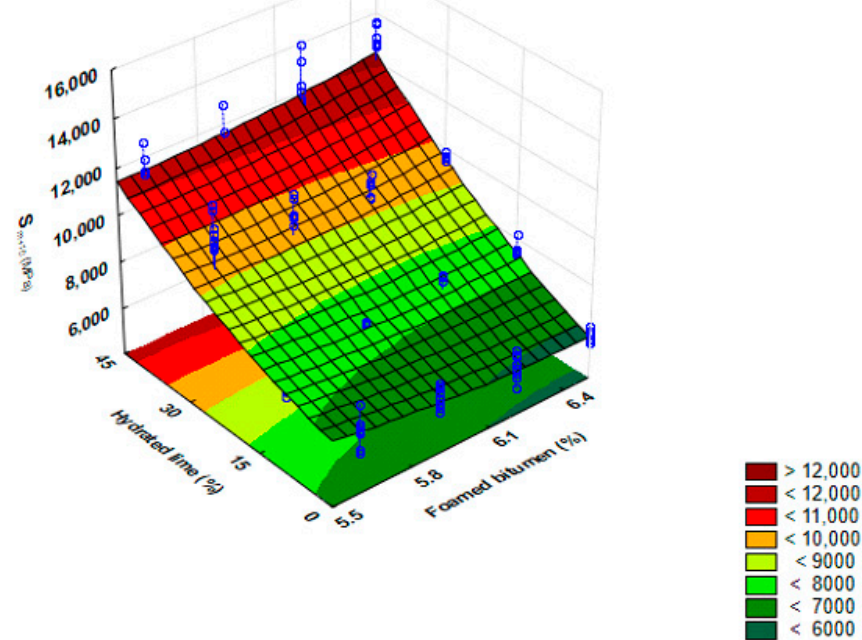

(c)

Figure 8. Cont. 


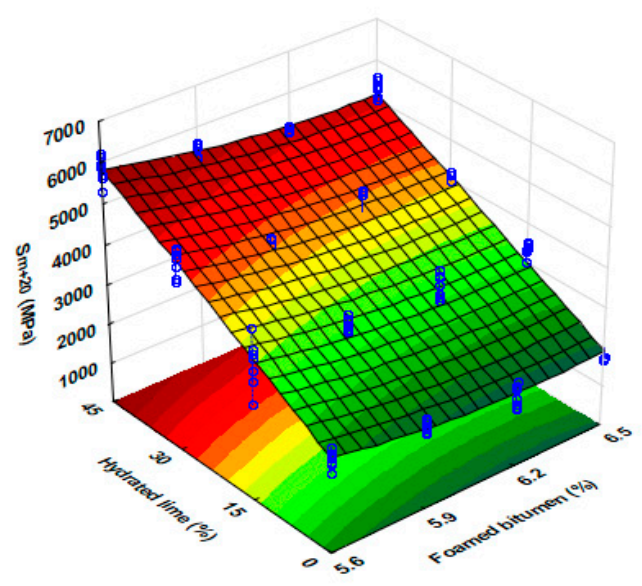

(d)

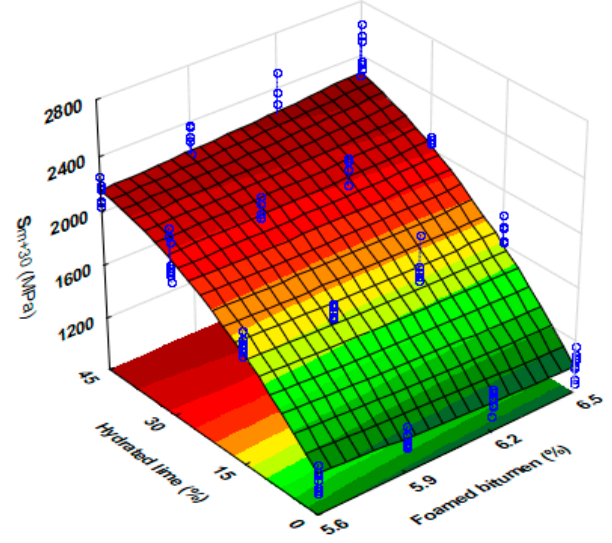

(e)

Figure 8. Stiffness modulus $\left(S_{m}\right)$ as a function of test temperature and amount of foamed bitumen and hydrated lime; models describing these relationships. (a) $\mathrm{S}_{\mathrm{m}-10}=31,976.2-4250.8 \mathrm{FB}+535.1 \mathrm{FB}^{2}-$ $560.6 \mathrm{HL}+2.2 \mathrm{HL}^{2}+100.4 \mathrm{FB} \mathrm{HL},(\mathbf{b}) \mathrm{S}_{\mathrm{m} 0}=-14,876.7+6178.5 \mathrm{FB}-203.2 \mathrm{FB}^{2}-178.1 \mathrm{HL}-0.8 \mathrm{HL}^{2}+$ 61.4 FB HL, (c) $\mathrm{S}_{\mathrm{m} 10}=42,843.7-11,206.5 \mathrm{FB}+846.5 \mathrm{FB}^{2}-194.2 \mathrm{HL}+1.2 \mathrm{HL}^{2}+43.8 \mathrm{FB} \mathrm{HL},(\mathbf{d}) \mathrm{S}_{\mathrm{m} 20}=$ $44,108.5-13,433.1 \mathrm{FB}+1068.0 \mathrm{FB}^{2}+117.0 \mathrm{HL}-0.1 \mathrm{HL}^{2}-6.4 \mathrm{FB} \mathrm{HL}$, (e) $\mathrm{S}_{\mathrm{m} 30}=4073.4-872.1 \mathrm{FB}+$ $61.3 \mathrm{FB}^{2}+6.5 \mathrm{HL}-0.4 \mathrm{HL}^{2}+6.0 \mathrm{FB} \mathrm{HL}$.

A comprehensive analysis of the results based on the data in Figure 8 indicates that at $-10{ }^{\circ} \mathrm{C}$, the value of the stiffness modulus $\left(\mathrm{S}_{\mathrm{m}-10}\right)$ shows no significant increase, with the amount of foamed bitumen increasing from $5.9 \%$ to $6.2 \%$, and the amount of hydrated lime increasing from $15 \%$ to $30 \%$. There is an interaction between the hydrated lime and foamed bitumen for providing AC $8 \mathrm{~S}$ with the resistance to low temperatures. The use of foamed bitumen in this quantity will have an advantageous effect on AC performance at low temperatures, making it less susceptible to low-temperature cracking than HMA.

In the entire domain of the experiment, an increase in the content of foamed bitumen and hydrated lime steadily increased the value of the stiffness modulus $\left(\mathrm{S}_{\mathrm{m} 0}\right)$, with the highest increase rate occurring diagonally across the foamed bitumen/hydrated lime relationship. The hydrated lime interacts with foamed bitumen, and provides AC $8 \mathrm{~S}$ with the resistance to low temperatures. The most advantageous effect was observed for the hydrated lime used at $30 \%$, as a replacement for the mineral filler. 
A detailed analysis of $\mathrm{S}_{\mathrm{m}}$ results within the test temperature range $10{ }^{\circ} \mathrm{C}$ to $30^{\circ} \mathrm{C}$ shows that the amount of the hydrated lime, increasing from $15 \%$ to $45 \%$, has a significant effect on the modulus value. At lower foamed bitumen content, the binder tends to interact with the hydrated lime, and this interaction increases the stiffness modulus of the AC $8 \mathrm{~S}$ mixture.

To assess the effect of hydrated lime and foamed bitumen 50/70 with the addition of $0.6 \%$ SAA on the properties of the AC $8 \mathrm{~S}$ bituminous mixture, the correlation between the air void content $\left(\mathrm{V}_{\mathrm{a}}\right)$ and stiffness modulus $\left(\mathrm{S}_{\mathrm{m}}\right)$ was analyzed (Figure 9$)$.

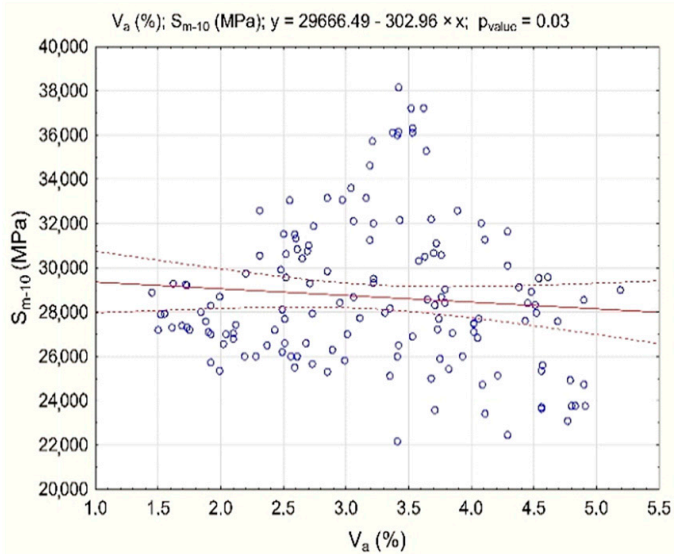

(a)

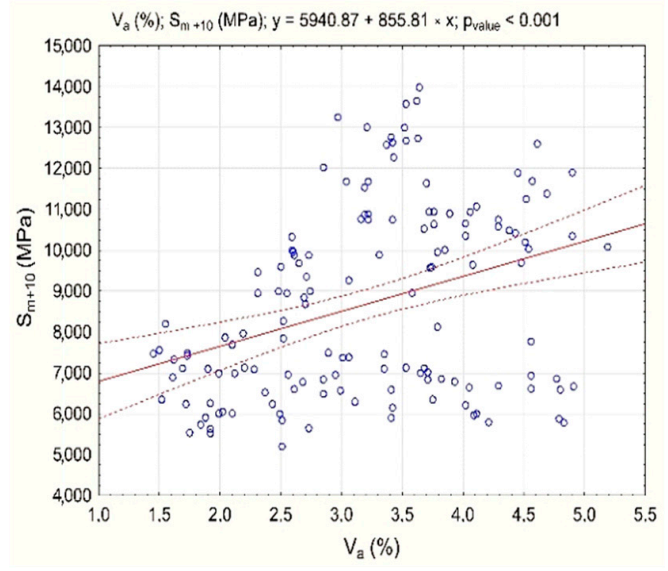

(c)

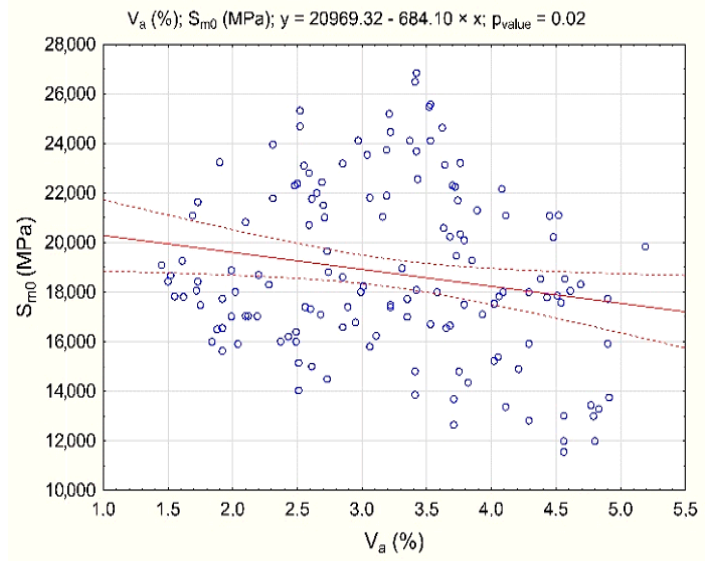

(b)

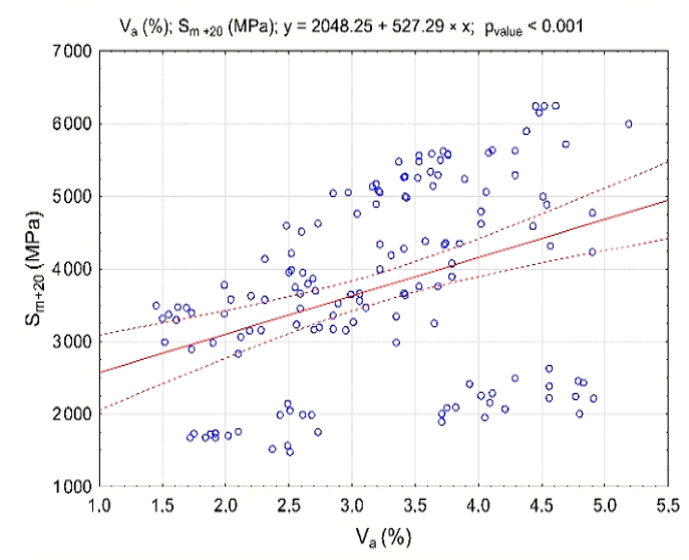

(d)

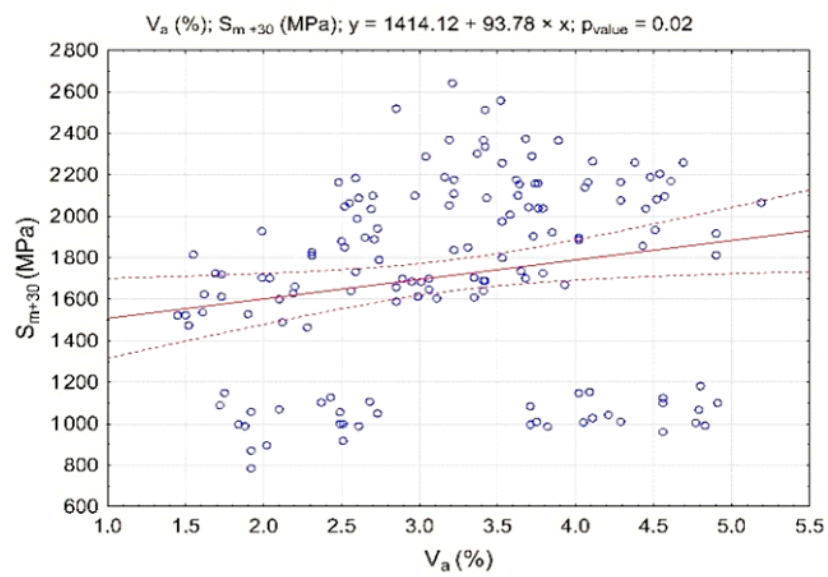

(e)

Figure 9. Correlation between AC $8 \mathrm{~S}$ mixture air void content $\left(\mathrm{V}_{\mathrm{a}}\right)$ and stiffness modulus $\mathrm{S}_{\mathrm{m}}$; (a) $\mathrm{S}_{\mathrm{m}-10}$, (b) $\mathrm{S}_{\mathrm{m} 0}$, (c) $\mathrm{S}_{\mathrm{m}+10}$, (d) $\mathrm{S}_{\mathrm{m}+20}$, (e) $\mathrm{S}_{\mathrm{m}+30}$. Dotted lines represent $95 \%$ confidence interval. 
The statistically significant correlation between the air void content $\left(\mathrm{V}_{\mathrm{a}}\right)$ of AC $8 \mathrm{~S}$ and the stiffness modulus $\left(S_{m}\right)$ has a linear character ( $p$-value less than $\left.\alpha=0.05\right)$.

\subsection{Optimization of the Foamed Bitumen and Hydrated Lime Content in Terms of Service Durability of} HWMA Concrete AC $8 \mathrm{~S}$

An important element of the assessment of the impact of hydrated lime and foamed bitumen $50 / 70$ modified with $0.6 \%$ SAA is the analysis of the relationships between the assessed properties of asphalt concrete AC 8 S. The analysis is summarized as correlations in Table 7 [74].

Table 7. Correlations between AC $8 \mathrm{~S}$ parameters.

\begin{tabular}{ccccccc}
\hline Variable & $\left.\mathbf{S}_{\mathbf{m}-\mathbf{1 0}} \mathbf{( M P a}\right)$ & $\left.\mathbf{S}_{\mathbf{m}+\mathbf{3 0}} \mathbf{( M P a}\right)$ & $\mathbf{S}_{\mathbf{m + 2 0}}(\mathbf{M P a})$ & $\left.\mathbf{S}_{\mathbf{m + 1 0}} \mathbf{( M P a}\right)$ & $\left.\mathbf{S}_{\mathbf{m} \mathbf{0}} \mathbf{( M P a}\right)$ & $\mathbf{V}_{\mathbf{a}}(\mathbf{\%})$ \\
\hline $\mathrm{S}_{\mathrm{m}-10}(\mathrm{MPa})$ & 1.000 & 0.719 & 0.617 & 0.731 & 0.806 & -0.086 \\
& $p=---$ & $p \leq 0.001$ & $p \leq 0.001$ & $p \leq 0.001$ & $p \leq 0.001$ & $p=0.30$ \\
\hline $\mathrm{S}_{\mathrm{m}+30}(\mathrm{MPa})$ & 0.719 & 1.000 & 0.912 & 0.847 & 0.756 & 0.191 \\
& $p \leq 0.001$ & $p=--$ & $p \leq 0.001$ & $p \leq 0.001$ & $p \leq 0.001$ & $p=0.02$ \\
\hline $\mathrm{S}_{\mathrm{m}+20}(\mathrm{MPa})$ & 0.617 & 0.9122 & 1.000 & 0.869 & 0.645 & 0.377 \\
& $p \leq 0.001$ & $p \leq 0.001$ & $p=---$ & $p \leq 0.001$ & $p \leq 0.001$ & $p \leq 0.001$ \\
\hline $\mathrm{S}_{\mathrm{m}+10}(\mathrm{MPa})$ & 0,731 & 0.847 & 0.869 & 1.000 & 0,696 & 0.347 \\
& $p \leq 0.001$ & $p \leq 0.001$ & $p \leq 0.001$ & $p=--$ & $p \leq 0.001$ & $p \leq 0.001$ \\
\hline $\mathrm{S}_{\mathrm{m} 0}(\mathrm{MPa})$ & 0.805 & 0.756 & 0.645 & 0.696 & 1.000 & -0.187 \\
& $p \leq 0.001$ & $p \leq 0.001$ & $p \leq 0.001$ & $p \leq 0.001$ & $P=---$ & $p=0.02$ \\
\hline $\mathrm{V}_{\mathrm{a}}(\%)$ & -0.086 & 0.191 & 0.377 & 0.347 & -0.187 & 1.000 \\
& $p=0.303$ & $p=0.022$ & $p \leq 0.001$ & $p \leq 0.001$ & $p=0.025$ & $p=-$ \\
\hline
\end{tabular}

Correlations and correlation coefficients are significant when $p<0.05$.

The main correlation parameter was the content of air voids $\mathrm{V}_{\mathrm{a}}$, which had a significant impact on other properties of asphalt concrete AC $8 \mathrm{~S}$. It can be concluded that the correlations between virtually all analyzed properties, except the stiffness modulus $\left(\mathrm{S}_{\mathrm{m}-10}\right)$ at $-10{ }^{\circ} \mathrm{C}$, are statistically significant, although not at the highest level. This effect may be related to the specific conditions (temperature $-10{ }^{\circ} \mathrm{C}$ ) of the test. The correlation values correspond to the analysis results obtained from the experiment, which shows that either most of the results are non-linear or statistically significant interactions occurred.

When assessing the impact of additives in both bitumen (50/70) and asphalt concrete mixtures (AC $8 \mathrm{~S}$ ), it is very important to optimize them using the obtained mathematical regression models and statistical analysis program $[73,74]$.

For ensuring the most favorable properties of AC $8 \mathrm{~S}$, the recommended amount of hydrated lime and foamed bitumen was determined through the analysis of the results from a simultaneous response optimization of the following parameters (variables):

- $\quad$ air void content $\left(\mathrm{V}_{\mathrm{a}}\right)$ according to WT-2 2014 [68],

- stiffness modulus at $-10{ }^{\circ} \mathrm{C}, 0{ }^{\circ} \mathrm{C},+10^{\circ} \mathrm{C},+20^{\circ} \mathrm{C}$, and $+30{ }^{\circ} \mathrm{C}$, according to EN 12697-26, and depending on the content of the foamed bitumen and hydrated lime in HWMA concrete AC $8 \mathrm{~S}$.

The models for the optimized variables are summarized in Table 8. 
Table 8. Parameters of the models characterizing the variables subjected to optimization.

\begin{tabular}{cccccccccc}
\hline \multirow{2}{*}{$\begin{array}{c}\text { Dependent } \\
\text { Variable }\end{array}$} & $\begin{array}{c}\text { Sulticrit. } \\
\mathbf{R}\end{array}$ & $\begin{array}{c}\text { Multicrit. } \\
\mathbf{R}^{\mathbf{2}}\end{array}$ & $\begin{array}{c}\text { Adjusted. } \\
\mathbf{R}^{\mathbf{2}}\end{array}$ & $\begin{array}{c}\text { SS } \\
\text { Model }\end{array}$ & $\begin{array}{c}\text { MS } \\
\text { Model }\end{array}$ & $\begin{array}{c}\text { SS } \\
\text { Residual }\end{array}$ & $\begin{array}{c}\text { MS } \\
\text { Residual }\end{array}$ & F & $p$ \\
\hline $\mathrm{V}_{\mathrm{a}}(\%)$ & 0.908 & 0.826 & 0.821 & $1.043 \times 10^{2}$ & 26 & 22 & 0 & 165.1 & $<0.001$ \\
$\mathrm{~S}_{\mathrm{m}-10}(\mathrm{MPa})$ & 0.888 & 0.789 & 0.783 & $1.224 \times 10^{9}$ & $305,969,940$ & $326,976,774$ & $2,352,351$ & 130.0 & $<0.001$ \\
$\mathrm{~S}_{\mathrm{m} 0}(\mathrm{MPa})$ & 0.920 & 0.846 & 0.842 & $1.435 \times 10^{9}$ & $358,641,446$ & $259,957,219$ & $1,870,196$ & 191.7 & $<0.001$ \\
$\mathrm{~S}_{\mathrm{m}+10}(\mathrm{MPa})$ & 0.927 & 0.860 & 0.856 & $6.603 \times 10^{8}$ & $165,078,470$ & $107,443,778$ & 772,977 & 213.5 & $<0.001$ \\
$\mathrm{~S}_{\mathrm{m}+20}(\mathrm{MPa})$ & 0.971 & 0.942 & 0.941 & $2.325 \times 10^{8}$ & $58,116,523$ & $14,086,527$ & 101,342 & 573.4 & $<0.001$ \\
$\mathrm{~S}_{\mathrm{m}+30}(\mathrm{MPa})$ & 0.960 & 0.923 & 0.920 & $2.811 \times 10^{7}$ & $7,028,122$ & $2,340,397$ & 16,837 & 417.4 & $<0.001$ \\
\hline
\end{tabular}

The relationships described above and the evaluation of the values listed in Table 7 show that all analyzed models adequately describe the most important properties of AC $8 \mathrm{~S}$, and can be used to optimize its composition. The adjusted determination coefficient $\left(R^{2}\right)$ assumes values from 0.789 to 0.942 , which indicates a high reliability of the optimization parameters.

The performance of AC $8 \mathrm{~S}$ was measured using the following metrics: the most desirable parameter values were assigned the performance indicator equal to 1 , and the least desired values were assigned 0 . The used optimization procedure was described in detail in [75]. The following criteria were applied for the individual parameters of asphalt concrete:

Air void content $\mathrm{V}_{\mathrm{a}}(\max : 0$, min: 1$)$,

Stiffness modulus, $\mathrm{S}_{\mathrm{m}-10}$, according to WT-2 (max: 0, min: 1 ),

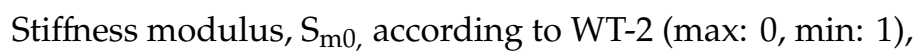

Stiffness modulus, $\mathrm{S}_{\mathrm{m}+10}$, according to WT-2 (max: 1 , min: 0 ),

Stiffness modulus, $\mathrm{S}_{\mathrm{m}+20}$, according to WT-2 (max: 1 , min: 0 ),

Stiffness modulus, $\mathrm{S}_{\mathrm{m}+30}$, according to WT-2 (max: 1 , min: 0 ),

The results of the optimization of hydrated lime and foamed bitumen in AC $8 \mathrm{~S}$ are shown in Figure 10.

The profiles of approximated values and the desirability of the adopted variables (asphalt concrete parameters) were analyzed, and the recommended content of foamed bitumen was determined at $5.8 \%$ and that of hydrated lime at $33.8 \%$. Considering the process of dosing the components of the asphalt concrete and their tolerances, the following recommended amounts were adopted: $5.9 \%$ of foamed bitumen $50 / 70$ containing $0.6 \%$ SAA and $30 \%$ of hydrated lime as a partial replacement for the mineral filler.

Assessment of the resistance of AC $8 \mathrm{~S}$ to permanent deformation was performed for the recommended content of foamed bitumen (5.9\%) and hydrated lime at $0 \%, 15 \%, 30 \%$, and $45 \%$, as per WT-2 2014 [68]. According to the requirements of WT-2 2014, AC 8 S should have WTS AIR $<0.15$ and $\mathrm{PRD}_{\text {AIR }}<9$ [68].

A graphical interpretation of the parameters representing the resistance of AC $8 \mathrm{~S}$ mixture to permanent deformation is shown in Figure 11. 


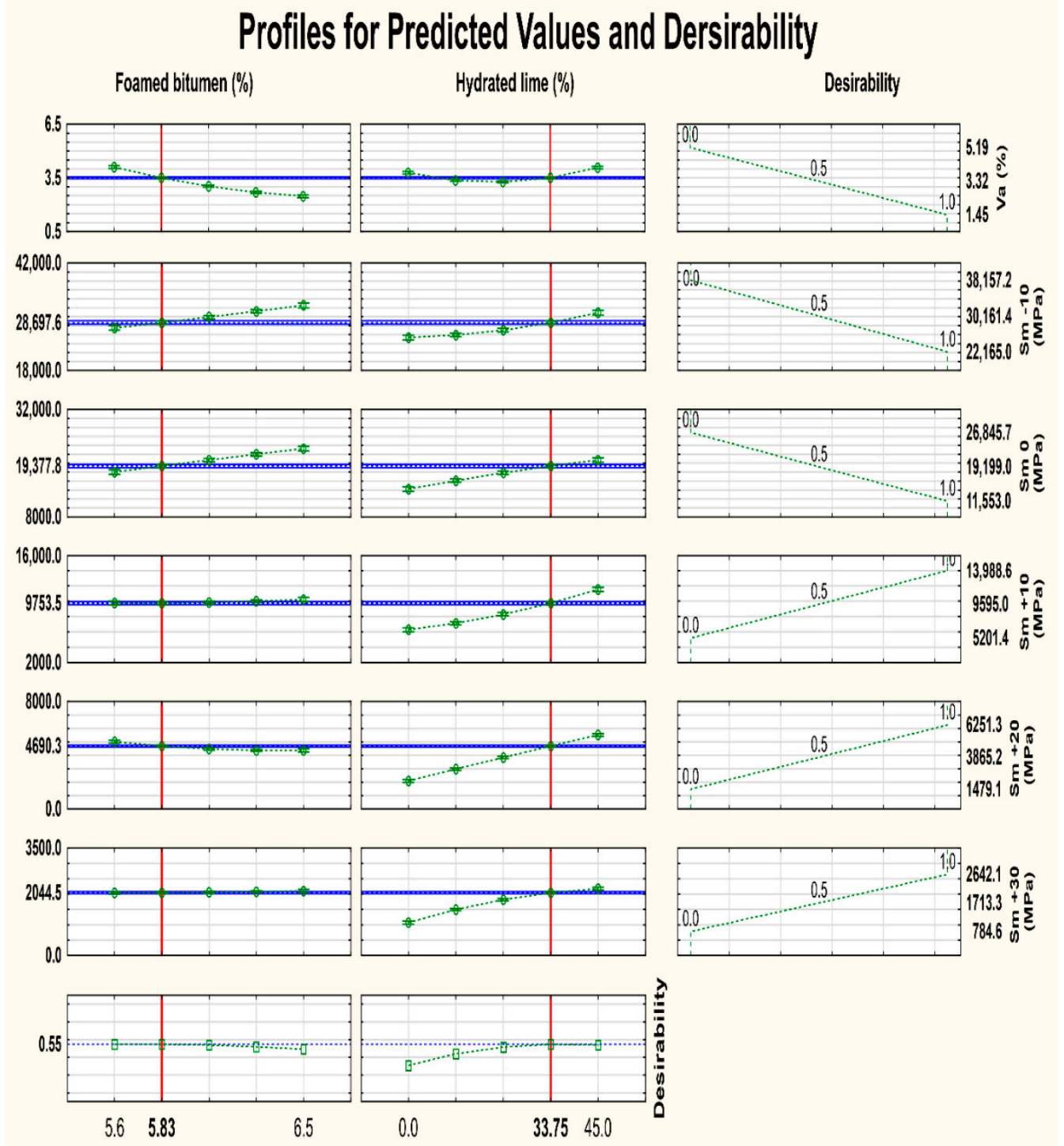

Figure 10. Profiles of approximated values and desirability function for the recommended amount of foamed bitumen and hydrated lime in asphalt concrete AC $8 \mathrm{~S}$.

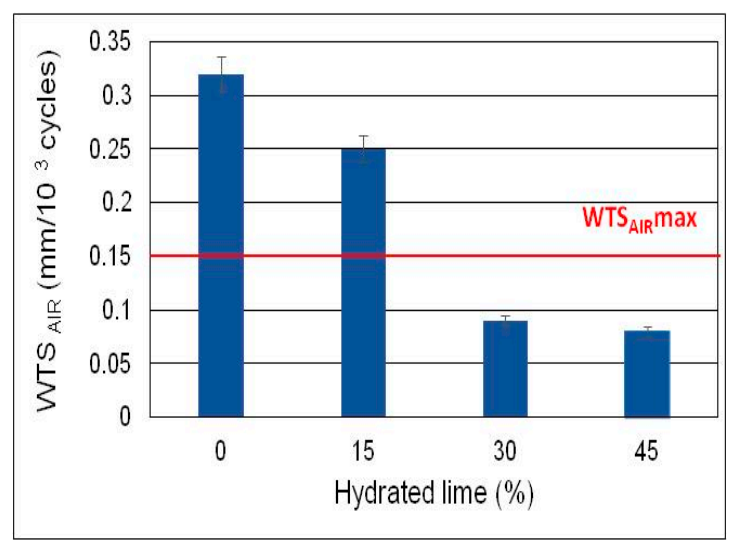

(a)

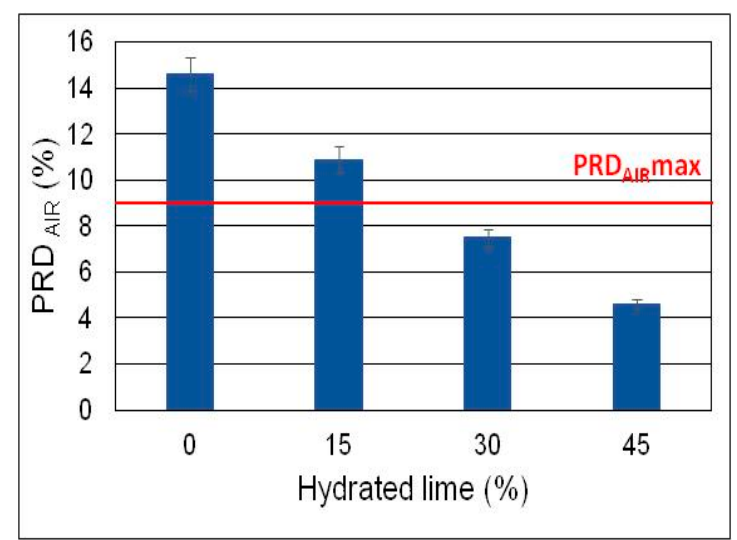

(b)

Figure 11. Resistance to permanent deformation of AC $8 \mathrm{~S}$ mixture at the recommended $5.9 \%$ content of foamed bitumen; (a) WTS AIR, (b) PRD $_{\text {AIR }}$. 
Analysis of the results indicates that hydrated lime significantly influences the resistance to permanent deformation of HWMA mixture AC $8 \mathrm{~S}$ produced with foamed bitumen 50/70 modified with $0.6 \mathrm{wt} \%$ of SAA. Having $30 \%$ hydrated lime in its composition, AC $8 \mathrm{~S}$ meets the normative requirements, and is resistant to permanent deformation. Increasing the amount of hydrated lime to $40 \%$ leads to a slight increase in the value of the WTS $_{\text {AIR }}$ parameter. A more significant effect of hydrated lime is observed in the $\mathrm{PRD}_{\text {AIR }}$ parameter. A $40 \% \mathrm{HL}$ content affects the stiffness modulus at $-10{ }^{\circ} \mathrm{C}$ more significantly than $30 \%$ HL content, which, as mentioned earlier, can promote low temperature cracking. For all these reasons, the $30 \%$ hydrated lime content, used as a partial replacement for the mineral filler, and the 5.9\% foamed bitumen content (bitumen 50/70 treated with 0.6\% SAA) were adopted as recommended in AC $8 \mathrm{~S}$ asphalt concrete.

The recommended composition in terms of the contents of foamed bitumen and hydrated lime ensures obtaining highly durable asphalt concrete AC $8 \mathrm{~S}$, as shown by the significant resistance to moisture, frost, and permanent deformation.

\section{Conclusions}

Comprehensive analysis of the test data was the basis for the following conclusions concerning the HWMA mixture AC 8S, produced with the addition of hydrated lime (HL):

- The content of air voids in AC $8 \mathrm{~S}$ shows an advantageous reduction with the addition of $15 \%$ hydrated lime (as a replacement of mineral filler) and at the content of SAA treated foamed bitumen of 5.6\%. However, a higher HL percentage tends to increase the air void content in the mixture yet again. This may be because at higher concentrations, hydrated lime hinders asphalt concrete compaction. On the other hand, increasing the amount of binder has a positive effect on air void reduction in AC S 8, though the trend is the same as at $5.6 \%$.

- The stiffness modulus tests conducted at $-10{ }^{\circ} \mathrm{C}$ and $0{ }^{\circ} \mathrm{C}$ revealed an advantageous effect of hydrated lime, when used at $30 \%$ to $45 \%$, and foamed bitumen 50/70 (modified with $0.6 \%$ SAA), when used at $5.9 \%$ to $6.5 \%$. It was found that the interaction between the contents of the hydrated lime and foamed bitumen had a substantial influence on the stiffness modulus, as did the hydrated lime, used at $30 \%$ to $45 \%$, at temperatures of $10^{\circ} \mathrm{C}, 20^{\circ} \mathrm{C}$, and $30^{\circ} \mathrm{C}$.

- Optimization of HWMA concrete AC $8 \mathrm{~S}$, in terms of its most relevant parameters allowed determining the optimum content of hydrated lime and foamed bitumen as $5.9 \%$ and $30 \%$, respectively (dose tolerance considered).

- The asphalt concrete containing 5.9\% bitumen 50/70 with $0.6 \%$ SAA, and hydrated lime content of $30 \%$ is characterized by high resistance to permanent deformation (WTS AIR $_{\text {and }}$ PRD $_{\text {AIR }}$ ), thereby ensuring the service durability of the pavement.

- The results of the tests revealed a significant effect of the SAA-modified (0.6\%) foamed bitumen $50 / 70$ and hydrated lime contents on the characteristics of HWMA mixture AC $8 \mathrm{~S}$. The synergistic effect of the two materials is variable, and depends on the parameter analyzed.

The results of the stiffness modulus tests in the temperature range from $-10{ }^{\circ} \mathrm{C}$ to $10{ }^{\circ} \mathrm{C}$ provide sufficient evidence to conclude that at temperatures below zero a AC 8 S-based pavement should perform well. No defects should appear. The high values of mechanical characteristics represented by the stiffness moduli at temperatures between $+20^{\circ} \mathrm{C}$ and $+30^{\circ} \mathrm{C}$ should ensure the resistance of the road surface to the effects of vehicle traffic. The values of $\mathrm{WTS}_{\mathrm{AIR}}$ and $\mathrm{PRD}_{\mathrm{AIR}}$ indicate a high resistance of AC $8 \mathrm{~S}$ to permanent deformation. This is particularly visible when hydrated lime content is $30 \%$,

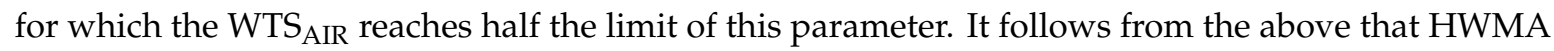
concrete AC $8 \mathrm{~S}$, produced with water-foamed bitumen and hydrated lime, can be recommended for road use (in situ) for a long-life deformation resistant asphalt concrete surface. 
Funding: This research was funded through grant DZP/RID-I-06/1/NCBR/2016 by the National Centre for Research and Development-Poland and the Polish General Directorate for National Roads and Motorways. The APC was funded by the Minister of Science and Higher Education grant number DZP/RID-I-06/1/NCBR/2016 The APC was funded by the and Minister of Science and Higher Education.

Acknowledgments: The manuscript was prepared through "The use of recycled materials" under RID project (The Development of Road Engineering Innovations DZP/RID-I-06/1/NCBR/2016) co-financed by the National Centre for Research and Development-Poland and the Polish General Directorate for National Roads and Motorways. The work is supported through the program of the Minister of Science and Higher Education "Regional Initiative of Excellence in 2019-2022" under project 025/RID/2018/19; PLN 12.000.000.

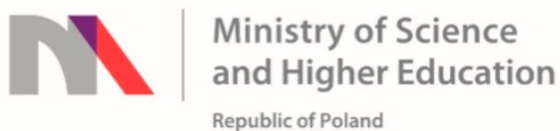

Conflicts of Interest: The author declare no conflict of interest.

\section{References}

1. Jenkins, K.J.; de Groot, J.L.A.; Van de Ven, M.F.C.; Molenaar, A.A.A. Half-warm Foamed Bitumen Treatment, A New Process. In Proceedings of the Conference on Asphalt Pavements for Southern Africa, Victoria Falls, Zimbabwe, 29 August-2 September 1999.

2. Chomicz-Kowalska, A.; Gardziejczyk, W.; Iwański, M. Moisture resistance and compactibility of asphalt concrete produced in half-warm mix asphalt technology with foamed bitumen. Constr. Build. Mater. 2016, 126, 8-118. [CrossRef]

3. Van De Ven, M.F.C.; Jenkins, K.J.; Voskuilen, J.L.M.; Beemt, R.V.D. Development of (half-) warm foamed bitumen mixes: State of the art. Int. J. Pavement Eng. 2007, 8, 163-175. [CrossRef]

4. Wirtgen GmbH. Wirtgen Cold Recycling Technology, 1st ed.; Wirtgen GmbH: Windhagen, Germany, 2012.

5. Jenkins, K.J. Mix Design Considerations for Cold and Half-Warm Bituminous Mixes with on Foamed Bitumen. Ph.D. Thesis, Department of Civil Engineering, Faculty of Engineering, University of Stellenbosch, Stellenbosch, South Africa, 2000.

6. Iwański, M.; Buczyński, P.; Mazurek, G. Optimization of the road binder used in the base layer in the road construction. Constr. Build. Mater. 2016, 125, 1044-1054. [CrossRef]

7. Ruckel, P.J.; Acott, S.M.; Bowering, R.H. Foamed-Asphalt Paving Mixtures: Preparation of Design Mixes and Treatment of Test Specimens. In Asphalt Materials, Mixtures, Construction, Moisture Effects and Sulfur; TRB-Transportation Research Board: Washington, DC, USA; National Research Council USA: Washington, DC, USA, 1982; Volume 911, pp. 88-95.

8. Iwański, M.; Chomicz-Kowalska, A. Water and frost resistance of the recycled base rehabilitated with foamed bitumen technology. In Proceedings of the 10th International Conference, Modern Building Materials, Structures and Techniques, Vilnius Gediminas Technical University, Vilnius, Lithuania, 19-21 May 2010; pp. 99-105.

9. Buczyński, P.; Iwański, M. Fatigue Life Comparison of Recycled Cold Mixes with Foamed Bitumen and with Bitumen Emulsion. Procedia Eng. 2017, 172, 135-142. [CrossRef]

10. Sengoz, B.; Topal, A.; Gorkem, C. Evaluation of natural zeolite as warm mix asphalt additive and its comparison with other warm mix additives. Constr. Build. Mater. 2013, 43, 242-252. [CrossRef]

11. Chomicz-Kowalska, A.; Maciejewski, K.; Iwański, M. Study of the Simultaneous Utilization of Mechanical Water Foaming and Zeolites and Their Effects on the Properties of Warm Mix Asphalt Concrete. Materials 2020, 13, 357. [CrossRef] [PubMed]

12. Woszuk, A.; Zofka, A.; Bandura, L.; Franus, W. Effect of zeolite properties on asphalt foaming. Constr. Build. Mater. 2017, 139, 247-255. [CrossRef]

13. Chomicz-Kowalska, A.; Iwański, M.M.; Mrugała, J. Basic Performance of Fibre Reinforced Asphalt Concrete with Reclaimed Asphalt Pavement Produced In Low Temperatures with Foamed Bitumen. IOP Conf. Ser. Mater. Sci. Eng. 2017, 245, 032092. [CrossRef] 
14. Silva, H.M.; Oliveira, J.R.; Peralta, J.; Zoorob, S.E. Optimization of warm mix asphalts using different blends of binders and synthetic paraffin wax contents. Constr. Build. Mater. 2010, 24, 1621-1631. [CrossRef]

15. Jamshidi, A.; Hamzah, M.O.; You, Z. Performance of Warm Mix Asphalt containing Sasobit ${ }^{\circledR}$ : State-of-the-art. Constr. Build. Mater. 2013, 38, 530-553. [CrossRef]

16. Iwański, M.; Mazurek, G. The influence of the low-viscosity modifier on viscoelasticity behavior of the bitumen at high operational temperature. In Proceedings of the 8th International Conference Environmental Engineering, Vilnius, Lithuania, 19-20 May 2011; Volume 1-3, pp. 1097-1102.

17. Yu, X.; Wang, Y.; Luo, Y. Impacts of water content on rheological properties and performance-related behaviors of foamed warm-mix asphalt. Constr. Build. Mater. 2013, 48, 203-209. [CrossRef]

18. Iwański, M.; Chomicz-Kowalska, A.; Maciejewski, K. Application of synthetic wax for improvement of foamed bitumen parameters. Constr. Build. Mater. 2015, 83, 62-69. [CrossRef]

19. Leng, Z.; Gamez, A.; Al-Qadi, I.L. Mechanical Property Characterization of Warm-Mix Asphalt Prepared with Chemical Additives. J. Mater. Civ. Eng. 2014, 26, 304-311. [CrossRef]

20. Mrugała, J.; Iwański, M.M. Resistance to Permanent Deformation of Asphalt Concrete with F-T Wax Modified Foamed Bitumen. Procedia Eng. 2015, 108, 459-466. [CrossRef]

21. Lu, X.; Redelius, P. Effect of bitumen wax on asphalt performance. Constr. Build. Mater. 2006, 21, 1961-1970. [CrossRef]

22. Iwański, M.; Mazurek, G. Effect of Fischer-Tropsch synthetic wax additive on the functional properties of bitumen. Polimery 2015, 60, 272-278. [CrossRef]

23. Iwański, M.; Chomicz-Kowalska, A. Evaluation of the pavement performance. Bull. Pol. Acad. Sci. Tech. Sci. 2015, 63, 97-105. [CrossRef]

24. Król, J.; Kowalski, K.; Radziszewski, P.; Sarnowski, M. Rheological behaviour of n-alkane modified bitumen in aspect of Warm Mix Asphalt technology. Constr. Build. Mater. 2015, 93, 703-710. [CrossRef]

25. Ai, C.; Li, J.Q.; Qiu, Y. Testing and assessing the performance of a new warm mix asphalt with SMC. J. Traffic Transp. Eng. 2015, 2, 399-405. [CrossRef]

26. Vega-Zamanillo, Á.; Calzada-Perez, M.; Sanchez-Alonso, E.; Gonzalo-Orden, H. Density, Adhesion and Stiffness of Warm Mix Asphalts. Procedia Soc. Behav. Sci. 2014, 160, 323-331. [CrossRef]

27. Sanchez-Alonso, E.; Vega-Zamanillo, Á.; Castro-Fresno, D.; DelRio-Prat, M. Evaluation of compactability and mechanical properties of bituminous mixes with warm additives. Constr. Build. Mater. 2011, 25, 2304-2311. [CrossRef]

28. Stefańczyk, B.; Mieczkowski, P. Dodatki, Katalizatory i Emulgatory w Mieszankach Mineralno-Asfaltowych (Additives, Catalysts and Emulsifiers in Asphalt Mixtures); WKŁ: Warszawa, Poland, 2010. (In Polish)

29. Iwański, M.M.; Chomicz-Kowalska, A.; Maciejewski, K. Effect of Surface Active Agent (SAA) on 50/70 Bitumen Foaming Characteristics. Materials 2019, 12, 3514. [CrossRef] [PubMed]

30. Piłat, J.; Radziszewski, P. Nawierzchnie Asfaltowe: Podręcznik Akademicki (Asphalt Pavements; Academic Handbook); WKiŁ: Warszawa, Poland, 2010. (In Polish)

31. Stefańczyk, B.; Mieczkowski, P. Mieszanki Mineralno-Asfaltowe: Wykonawstwo i Badania. (Bituminous Mixtures: Performance and Research); WKiŁ: Warszawa, Poland, 2008; p. 322. (In Polish)

32. Iwański, M.; Uriew, N.B. The Asphalt Concrete as a Composite Material (with Nanodisperse and Polymer Components); Moscow State Automobile and Road Technical University-Kielce Technical University (Poland): Moscow, Russia, 2007; p. 669.

33. Sebaaly, P.E.; Litte, D.N.; Epps, J.A. The Benefits of Hydrated Lime in Hot Mix Asphalt; The National Lime Association: Arlington, VA, USA, 2006.

34. Chachas, C.V.; Liddle, W.J.; Peterson, D.E.; Wiley, M.L. Use of Hydrated Lime in Bituminous Mixtures to Decrease Hardening of the Asphalt Cement; Report PB 231 170; Utah State Highway Department: Salt Lake City, UT, USA, 1971.

35. Hanson, D.I.; Graves, R.E.; Brown, E.E. Laboratory evaluation of the addition of lime treated sand to hot-mix asphalt. Transp. Res. Rec. 1994, 1469, 34-42.

36. Luxemburk, G.F. Lime Hydrate as an Additive to Improve the Adhesion of Bitumen to the Aggregates. In Proceedings of the II International Conference Durable and Save Road Pavements, Kielce, Poland, 15-16 May 1996; pp. 296-302.

37. Ramiączek, P.; Maciejewski, K.; Mateusz, M.I. Influence of hydrated lime on the properties of filler-bitumen composite. Struct. Environ. 2015, 2, 5-10. 
38. Petersen, J.C.; Plancher, H.; Hansberger, P.M. Lime treatment of asphalt to reduce age hardening and improve flow properties. In Proceedings of the Association Asphalt Paving Technologists, Reno, NY, USA, 23-25 February 1987; Volume 56, pp. 632-653.

39. Zou, J.; Isola, M.; Roque, R.; Chun, S.; Koh, C.; Lopp, G. Effect of hydrated lime on fracture performance of asphalt mixture. Constr. Build. Mater. 2013, 44, 302-308. [CrossRef]

40. Bagampadde, U.; Isacsson, U.; Kiggundu, B.M. Classical and contemporary aspects of stripping in bituminous mixes. Road Mater. Pavement Des. 2004, 5, 7-43. [CrossRef]

41. Curtis, K.; Ensley, K.; Epps, J. Fundamental Properties of Asphalt-Aggregate Interactions Including Adhesion and Absorption; SHRP Report A-341; National Research Council: Washington, DC, USA, 1993.

42. Stroup-Gardiner, M.; Newcomb, D. Comparison of dolomitic and normally hydrated lime as antistripping additives. Transp. Res. Rec. 1990, 1269, 56-68.

43. Huang, S.-C.; Petersen, J.C.; Robertson, R.; Branthaver, J.F. Effect of Hydrated Lime on Long-Term Oxidative Aging Characteristics of Asphalt. Transp. Res. Rec. 2002, 1810, 17-24. [CrossRef]

44. Iwański, M. Wapno Hydratyzowane Wielofunkcyjnym Dodatkiem Zwiększajacym Trwałość Nawierzchni SMA. (The Hydrated Lime with the Multi-Functional Additive Increasing the Durability of SMA Pavements); Politechnika Świętokrzyska. Monograph M59; Kielce University of Technology: Kielce, Poland, 2014; p. 200. (In Polish)

45. Blazek, J.; Debor, G.; Maxa, D.; Ajib, M.; Paniagua, H. Effect of hydrated lime addition on properties of asphalt. Pet. Coal 2000, 42, 41-45.

46. Baig, M.G.; Wahhab, H.I.A.-A. Mechanistic Evaluation of Hedmanite and Lime Modified Asphalt Concrete Mixtures. J. Mater. Civ. Eng. 1998, 10, 153-160. [CrossRef]

47. Lesueur, D.; Little, D.N. Effect of Hydrated Lime on Rheology, Fracture, and Aging of Bitumen. Transp. Res. Rec. 1999, 1661, 93-105. [CrossRef]

48. Lesueur, D.; Petit, J.; Ritter, H.-J. The mechanisms of hydrated lime modification of asphalt mixtures: A state-of-the-art review. Road Mater. Pavement Des. 2012, 14, 1-16. [CrossRef]

49. Plancher, H.; Green, E.L.; Petersen, J.C. Reduction of oxidation hardening of asphalts by treatment with hydrated lime-A mechanistic study. In Proceedings of the Association Asphalt Paving Technologists 45, New Orleans, LA, USA, 16-18 February 1976; pp. 1-24.

50. Decoene, Y. Enrobes bitumineux permeables, experiences recentes belges. La Tech. Rout. 1983, 2, $20-40$.

51. Little, D.N.; Petersen, J.C. Unique effects of hydrated lime filler on the performance-related properties of asphalt cements: Physical and chemical interactions revisited. J. Mater. Civ. Eng. 2005, 17, 207-219. [CrossRef]

52. Oliver, H.W.J. Results of road trials of two asphalt antioxidants. Transp. Res. Rec. 1995, 1488, 96-102.

53. Gorkem, C.; Sengoz, B. Predicting stripping and moisture induced damage of asphalt concrete prepared with polymer modified bitumen and hydrated lime. Constr. Build. Mater. 2009, 23, 2227-2236. [CrossRef]

54. Hopman, P.C. Hydroxide in Filler, Netherlands Pavement Consulting Report No 97316; Netherlands Pavement Consulting: Ultrecht, The Netherlands, 1998.

55. Pickering, K.; Sebaaly, P.E.; Stroup-Gardiner, M.; Epps, A. Evaluation of new generation of antistripping additives. Transp. Res. Rec. 1992, 1342, 26-34.

56. Stroup-Gardiner, M.; Epps, J.A. Four variables that affect the performance of lime in asphalt aggregate mixtures. Transp. Res. Rec. 1987, 1115, 12-22.

57. Thiago Sacramento Aragao, F.T.S.; Lee, J.; Kim, Y.-R.; Karki, P. Material-specific effects hydrated lime on the properties and performance behavior on asphalt mixtures and asphaltic pavements. Constr. Build. Mater. 2010, 24, 538-544. [CrossRef]

58. Verhasselt, A.; Puiatti, D. Effect of hydrated lime on ageing of bituminous mastics. In Proceedings of the 3rd Euroasphalt and Eurobitume Congress, Vienna, Austria, 12-14 May 2004; Volume 1, pp. 746-756.

59. Grabowski, W.; Wilanowicz, J.; Sobol, T. Structural and functional properties of mineral fillers modified with hydrated lime. In Proceedings of the 6th International Conference on Maintenance and Rehabilitation of Pavements and Technological Control (MAIREPAV6), Torino, Italy, 8-10 July 2009; p. 78.

60. Grabowski, W.; Wilanowicz, J. Struktura wypełniaczy wapiennych a ich właściwości usztywniające w zaczynach asfaltowych (The structure of limestone fillers and their stiffening properties in asphalt mastic). Drogownictwo 1997, 12, 378-382. (In Polish)

61. Wortelboer, J.P.; Hoppen, H.J.; Ramond, G.; Pastor, M. Rheological properties of bitumen/filler mixtures. In Proceedings of the 1st Euroasphalt and Eurobitum Congress, Strasbourg, France, 7-10 May 1996; p. 4079. 
62. Witczak, M.W.; Bari, J. Development of a Master Curve (E* Database for Lime Modified Asphaltic Mixtures; Arizona State University Research Report: Tempe, AZ, USA, 2004.

63. Bari, J.; Witczak, M.W. Evaluation of the Effect of Lime Modification on the Dymanic Modulus Stiffness of Hot-Mix Asphalt: Use with the New Mechanistic-Empirical Pavement Design Guide. Transp. Res. Rec. 1929, 2005, 10-19.

64. Kim, Y.-R.; Lutif, J.S.; Bhasin, A.; Little, D.N. Evaluation of Moisture Damage Mechanisms and Effects of Hydrated Lime in Asphalt Mixtures through Measurements of Mixture Component Properties and Performance Testing. J. Mater. Civ. Eng. 2008, 20, 659-667. [CrossRef]

65. Kennedy, T.W.; Turnham, N.; Epps, J.A.; Smoot, C.W.; Young, F.M.; Button, J.W.; Zeigler, C.D. Evaluation of methods for field applications of lime to asphalt concrete mixtures. In Proceedings of the Association Asphalt Paving Technologists 52, Reno, NV, USA; 1983; pp. 508-534.

66. Hesami, S.; Roshani, H.; Hamedi, G.H.; Azarhoosh, A. Evaluate the mechanism of the effect of hydrated lime on moisture damage of warm mix asphalt. Constr. Build. Mater. 2013, 47, 935-941. [CrossRef]

67. Khodaii, A.; Tehrani, H.K.; Haghshenas, H. Hydrated lime effect on moisture susceptibility of warm mix asphalt. Constr. Build. Mater. 2012, 36, 165-170. [CrossRef]

68. WT-2. Technical Guidelines 2: Asphalt Pavements for National Roads. Part I: Asphalt Mixes; General Directorate for National Roads and Motorways: Warsaw, Poland, 2014; p. 48.

69. Judycki, J.; Jaskuła, P.; Pszczoła, M.; Alenowicz, J.; Dołżycki, B.; Jaczewski, M.; Ryś, D.; Stienss, M. Katalog Typowych Konstrukcji Nawierzchni Podatnych i Pótsztywnych (Catalogue of Typical Flexible and Semi-Rigid Pavement Constructions); GDDKiA: Warsaw, Poland, 2014; p. 112. (In Polish)

70. Pralińska, M.; Praliński, J. Badania Statystyczne z Excelem. (Investigations in Statistics with Excel); Wydawnictwo SGGW: Warszawa, Poland, 2007; p. 223. (In Polish)

71. Koronacki, J.; Mielniczuk, J. Statystyka dla Studentów Kierunków Technicznych i Przyrodniczych. (Statistics for Technical and Natural Sciences Students); Wydawnictwa Naukowo-Techniczne: Warszawa, Poland, 2004. (In Polish)

72. Iwański, M.M.; Chomicz-Kowalska, A.; Maciejewski, K. Resistance to Moisture Induced Damage of Half Warm Mix Asphalt Concrete with Foamed Bitumen. Materials 2020, 13, 654. [CrossRef]

73. Piasta, Z.; Lenarcik, A. Methods of statistical multi-criteria optimization. In Optimization Methods for Material Design of Cement-Based Composites; Brandt, A.M., Ed.; E \& FN Soon: London, UK; New York, NY, USA, 1998; pp. 45-59.

74. STATISTICA 13.3. Statsoft. Available online: www.statsoft.com (accessed on 20 August 2019).

75. Chomicz-Kowalska, A.; Maciejewski, K. Multivariate optimization of recycled road base cold mixtures with foamed bitumen. Procedia Eng. 2015, 108, 436-444. [CrossRef]

Publisher's Note: MDPI stays neutral with regard to jurisdictional claims in published maps and institutional affiliations.

(C) 2020 by the author. Licensee MDPI, Basel, Switzerland. This article is an open access article distributed under the terms and conditions of the Creative Commons Attribution (CC BY) license (http://creativecommons.org/licenses/by/4.0/). 